\title{
The Pandemic Management Theory. COVID-19 and biocentric development
}

\begin{abstract}
BACKGROUND
The Pandemic Management Theory (PMT) is a psychological theory based on the biocentric health management approach. It uses the data obtained in the study to describe an external first circle. Six phases of coping with the burden of the lockdown and the further load process of the COVID-19 pandemic are defined, such as the orientation phase with load interpretations, acute and chronic phases of negative load consequences and phases with positive consequences. Furthermore, it describes a phase with a biocentric sustainable change in ethical attitudes to protect life during pandemics.
\end{abstract}

\section{PARTICIPANTS AND PROCEDURE}

The empirical base for the description of the Theory is a study on the psychological processing of the COVID-19 crisis. A total of 1500 participants from 5 continents took part.

\section{RESULTS}

The COVID-19 crisis is an individual and genre-specific identity crisis in which basic ethical attitudes towards life are questioned, where the social distancing and restrictions have a separating, dissociating effect on the integration process with different levels of life. Therefore the inner circle of the model approaches biocentric connections of humans to (1) themselves, (2) to others and (3) to the "complex of living elements", to nature. Maintaining a connection in these three levels is necessary to sustain a healthy identity during pandemics. The causes and consequences of separations from these levels of life because of biocentric boundaries, which are defined in the model.

\section{CONCLUSIONS}

To protect the connection of humans to themselves, to others and to the complex of living beings (nature) support options are shown in six biocentric fields of action during and after pandemics: (1) maintaining affective communication, (2) maintenance of lively corporeality, (3) contact with one's own identity and inner oriented self-reflexion together with others, (4) construction of life sense and expression of life potentials, (5) expansion of consciousness and perception of the wholeness, (6) development of ecological awareness and sustainable biocentric lifestyles and attitudes.

\section{KEY WORDS}

biocentric approach; biocentric development; psychological coping with pandemic; pandemic management; psychoneuroimmunology and pandemic

ORGANIZATION - DPFA Academy of Work and Health, Leipzig, Germany; International Research Academy BIONET,

Leipzig, Germany

AUthors' Contributions - A: Study design - B: Data collection - C: Statistical analysis - D: Data interpretation .

E: Manuscript preparation · F: Literature search $\cdot$ G: Funds collection

CORRESPONDIng AUTHOR - Prof. Dr. habil. Marcus Stueck, DPFA Academy of Work and Health, Täubchenweg 83,

04317 Leipzig, Germany, e-mail: marcus.stueck@dpfa.de

to Cite this ARTICLE - Stueck, M. (2021). The Pandemic Management Theory. COVID-19 and biocentric development.

Health Psychology Report, 9(2), 101-128. https://doi.org/10.5114/hpr.2021.103123

RECEIVED 09.10.2020 • REVIEWED 10.11.2020 • ACCEPTED 28.11.2020 • PUBLISHED 28.01.2021 


\section{BACKGROUND}

The COVID-19 virus first appeared in December 2019 in the Chinese city of Wuhan. On March 11, 2020, the WHO officially declared the outbreak a pandemic due to the rapid increase in infections outside of China. Since its discovery, many scientific papers have been carried out on medical containment and mechanisms of action, especially regarding the medical treatment of the virus infection and its symptoms as well as the organization of treatment in hospitals. There are also a number of studies on how pandemics of this magnitude affect people who are psychologically affected and burdened by the restrictive governmental measures (Bidzan et al., 2020; Schröder et al., 2020) in the short and long term. Röhr et al. (2020) provide an overview of the psychosocial consequences of quarantine measures in a systematic review, with quarantine measures being consistently associated with negative psychosocial results in 13 evaluated studies. These included the occurrence of depressive symptoms, anxiety, anger, stress, post-traumatic stress, social isolation, loneliness, and stigma. So far, however, there is no evidence-based and comprehensive theory to describe the psychological effect mechanisms behind the effects of coping with or processing a pandemic, as e.g. in the event of terrorist attacks (Greenberg, 2012; Tichy, 2013). In this theory, fear of death is assumed to be the central trigger for changes in self-esteem and the change in cultural values after terrorist attacks and has been proven in studies. Fears also play a central role in the COVID-19 crisis, and in the Pandemic Management Theory (PMT), but there are many more fears that occur and have an impact on the burden experience and on individual and collective identity and coping processes. The crisis is more complex in terms of its existential effects on social and working life and so it can be explained that the theory must also be more complex. The Pandemic Management Theory contains two circles, which are shown in Figure 1.

The outer circle describes seven psychological process phases that individuals can go through in dealing with burden and loads during a pandemic. The inner circle is the centre of the Pandemic Management Theory, in which the underlying mechanisms of action behind these seven processing phases are described based on the biocentric management approach (Stueck, 2021) and the biocentric approach of Toro (Toro, 2010) and others. These include e.g. the destabilization process of identity and the immune system through fear. Strategies for action, so-called biocentric fields of action, which contribute to overcoming this pandemic crisis and the associated destabilization processes as well as a 'biocentric', life-protecting growth after pandemic stress are also described. The Pandemic Management Theory forms the basis of an international study that was carried out at the DPFA Academy of Work and Health with 9 international universities and a total of 1500 participants and began in Germany on March 27, 2020, 6 days after the lockdown and has been continued with process surveys.

\section{THEORETICAL COMPONENTS OF THE EXTERNAL CIRCLE OF PANDEMIC MANAGEMENT THEORY}

The external sphere of action consists of the coping with the situations of burden during the pandemic and their assessments, which are influenced by situational and habitual factors and coping skills or psychological resources. Also, it considers the development of negative or positive effects of different subjective load interpretations, which contribute to maintaining health or illness (see Figure 2) and the criteria for the transitions between the model phases (Table 3). These components are based on:

- The Burden-Load-Model about positive and negative consequences of load interpretations (Lazarus, 1999; Rohmert \& Rutenfranz, 1975; Scheuch \& Schröder, 1990; Stueck, 2008),

- The Chrono-bio-psychological Burden-Model (Balzer \& Stueck, 2021; Stueck et al., 2005),

- Coping models of loads, illness, disasters and stress prevention (Lazarus \& Launier, 1981; Schröder, 1996; Reschke \& Schröder, 2000; Stueck, 2009; Muthny, 1990; Horowitz, 2009; Khankeh et al., 2021; Witruk et al., 2009),

- Resource models (Antonovsky, 1987; Kobasa, 1990; Csikszentmihalyi \& Seligman, 2000),

- Works on the model of the zone of the next development (Vygotskij, 1932/2005; Keiler, 2002).

\section{THE SEVEN PHASES OF THE EXTERNAL CIRCLE OF THE PANDEMIC MANAGEMENT THEORY}

Based on the empirical observations and the theoretical background work of the PMT, six phases of dysregulation (negative effects) and regulation (positive effects) towards illness and health during pandemic periods were defined (see Figure 2).

Phase 1 - Orientation-phase with load interpretations of the pandemic situation (Figure 2, field 1-4)

In this phase the assessment of the pandemic situations by load interpretation of the situation takes place. The pandemic situations in the restriction phase have constant situational characteristics, including the closed borders, social isolation through exit restrictions, closed public institutions, shorttime work, and mask requirements. A person must deal adequately with these stimuli, in order to main- 


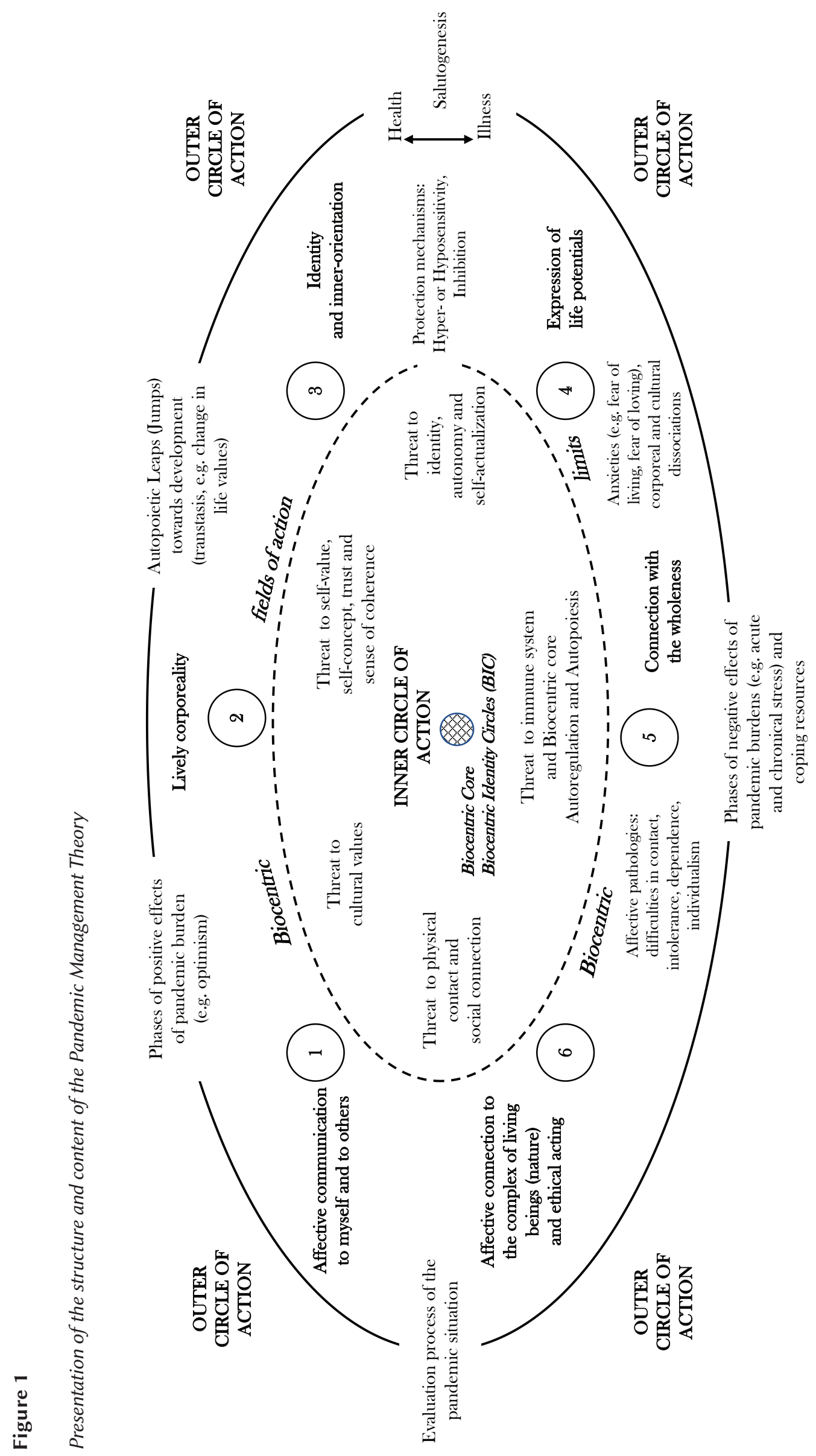

Biocentric health management and COVID-19 
Marcus Stueck

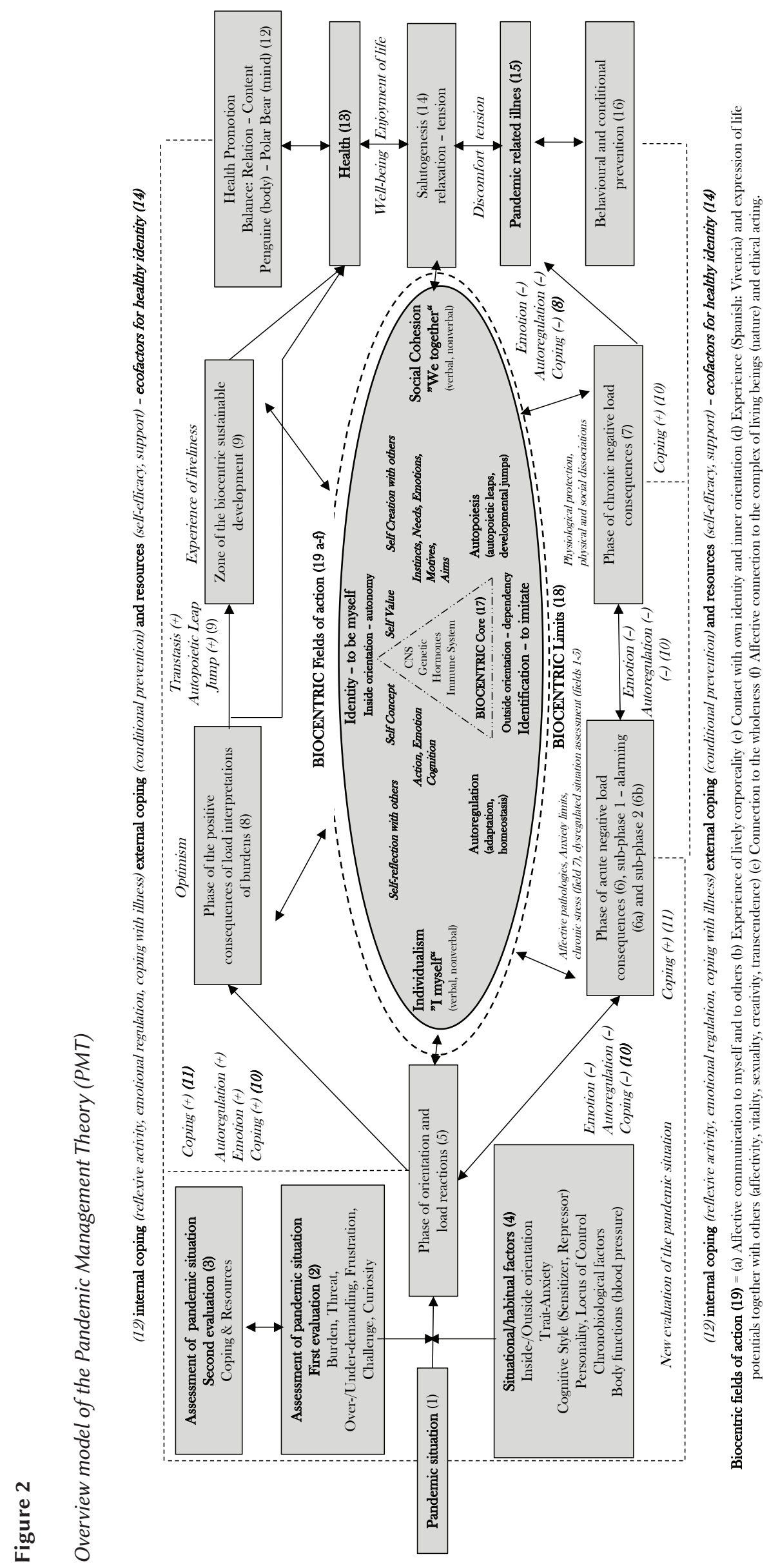


tain the balance to the environmental or bodily functions (homeostasis), to achieve goals and to satisfy their needs. The subjective effects of external pandemic burdens on people are known as loads that affect people due to their interpretation or assessment of the situation. Two evaluation processes take place unconsciously and continuously:

Situation and reaction-oriented evaluation (Figure 2, field 2): It is assessed whether the situation is a burden, threatening, under-/overwhelming or frustrating; or the situation is experienced as a challenge or arousing curiosity.

Assessment of coping resources (Figure 2, field 3): The second assessment answers the question of whether the individual has enough capacities to cope with the situation.

The relationship between burden situations in the lockdown or other pandemic situations and load interpretations begins with the perception or triggering of physiological arousal (including cardiovascular parameters or muscle tension (Balzer \& Stueck, 2021). This physiological feedback then influences the assessment processes. The assessment processes are also influenced by situational and habitual factors (Figure 2, field 4). Habitual characteristics are personality aspects or behaviour that are inherent to behaviour, have become habitual or are integral to the character (Table 1).

At the beginning of a pandemic, in the orientation phase, positive and negative load reactions arise.

Phase 2 - Phase of the pandemic load reactions (Figure 1, field 5)

It is a phase of short-term adaptability with the following load reactions depending on the assessment of 96 subjects in the first 14 days after the lockdown (without load consequences, Table 2).

The load reactions are processed with routine active or inner-psychological coping strategies. This includes the following coping processes:

- In the cognitive domain, assimilation and accommodation, i.e. classification of the experiences in existing or newly created explanatory patterns,

\section{Table 1}

Situational and habitual factors which influence the assessment of pandemic situations

\begin{tabular}{ll}
\hline Habitual factors (Figure 2, field 4) & Situational factors (Figure 2, field 4) \\
\hline - Inside orientation, outside orientation & - Coronavirus disease \\
- Anxiety and cognitive styles (suppressors, sensitizers) & - Situational social influencing factors \\
- Control beliefs and expectations of political influence & - support systems, money or possessions \\
- Risk attitude, overall personality & (material aids) \\
- Dysfunctional attitudes and extreme experiences & - Family, partnership \\
- Chronobiological and physical factors (chronotype, & \\
& \\
- blood pressure) & \\
\hline
\end{tabular}

\section{Table 2}

Qualitative responses from 96 people in the first 14 days after lockdown in Germany

\begin{tabular}{ll}
\hline Negative load reactions & Positive load reactions \\
\hline $\begin{array}{l}\text { Mentally (e.g. dealing with the subject of COVID-19, } \\
\text { mainly outside orientation) }\end{array}$ & $\begin{array}{l}\text { Mentally (e.g. appreciation of the carefree } \\
\text { life before COVID-19, inside orientation) }\end{array}$ \\
$\begin{array}{l}\text { Emotional (e.g. fear, frustration and annoyance, anger, } \\
\text { aggression, mood swings, insecurity, helplessness and }\end{array}$ & $\begin{array}{l}\text { Emotional (e.g. rest and relaxation, trust) } \\
\text { carelessness) }\end{array}$ \\
$\begin{array}{l}\text { Physically (e.g. blood pressure rises) } \\
\text { Behavioural (avoidance of contact in the personal } \\
\text { field, strengthening of contact in the wider environ- } \\
\text { ment (telephone), more or less movement, change }\end{array}$ & $\begin{array}{l}\text { Behavioural (e.g. slower behaviour, more } \\
\text { structured everyday life, increased contact } \\
\text { in the daily routine) }\end{array}$ \\
$\begin{array}{l}\text { Experience (disbelief in the face of the worldiends, prosocial behaviour, } \\
\text { lockdowns, bewilderment and shock) }\end{array}$ & $\begin{array}{l}\text { Experience (nature is experienced differently) } \\
\end{array}$ \\
\hline
\end{tabular}

Biocentric health management and COVID-19 
but also the initiation of cognition-controlled actions.

- In the emotional area the transformative observation of emotional states takes place (emotionbased regulation). After the attempt at coping a reassessment of the person-environment situation is undertaken (primary, secondary). The orientation phase does not trigger an emergency signal.

Phase 3 - Phase of acute, negative consequences of subjective load interpretations (Figure 2, field 6)

If the load reactions in pandemic situations cannot be coped with, acute misuse with negative consequences of load and burden occurs. This phase consists of 2 sub-phases:

a) Sub-phase 1 - acute load emergency signal reactions (Figure 2, field 6a): In sub-phase 1 (acute emergency signalling), if the negative consequences of the load reactions are not dealt with, load signals that indicate an emergency (problematic thoughts, fear equivalents, uncertainty, anger, feeling of helplessness, sadness, post-traumatic reactions) are generated. The level of action is mobilized with the associated psychophysiological activation in order to resolve the situation (search for information, direct action, inhibition of action, intrapsychic coping, see chapter Dealing with negative consequences of pandemic burden and loads). b) Sub-phase 2 - negative consequences of failure coping with acute negative load emergency signal reactions of sub-phase 1 (Figure 2, field 6 b): Only when these attempts to cope with 'the emergency' fail over a long period of time do negative consequences arise. The following negative load interpretation characteristics can result in:

- states of fatigue (when load interpretation of overwhelming, overload),

- experiencing monotony (when underwhelming, underload),

- experience of psychological satiety and annoyance (with frustration) and

- stress or anxiety reactions (in the case of threat assessments) (see Figure 3).

Phase 4-Phase of chronic symptoms of the negative load consequences (Figure 2, field 7)

If these acute negative load emergency signal reactions of sub-phase 2 over a longer period of time in a pandemic phase are not managed, then following chronic states of stress or states of fatigue arise (see Figure 3). It is a phase of the chronically disturbed adaptability to the pandemic circumstances with permanent mobilization and the depletion of energy reserves. Phase 4 of chronic misuse is accompanied by symptoms such as exhaustion, psychosomatic disorders, insomnia, inefficient action, self-esteem prob-

\section{Figure 3}

Overview about the acute negative load consequences (see Figure 2, field 6)
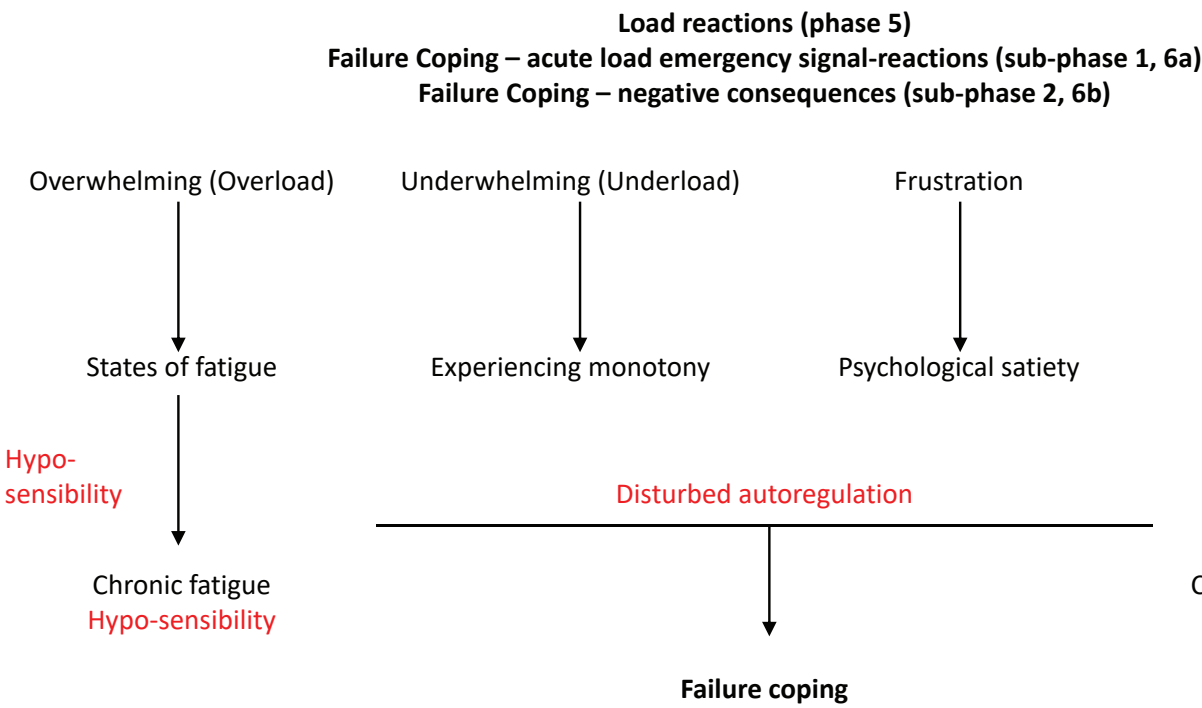

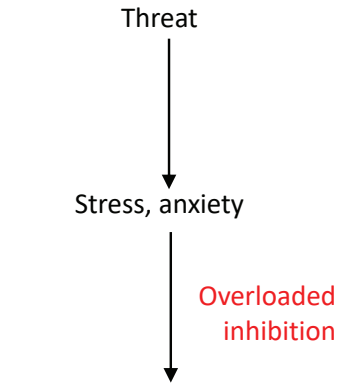

Chronic stress, generalized anxiety Hyper-sensibility

Exhaustion (Phase 4 of chronic symptoms of the negative load consequences) Psychosomatic disorders, insomnia, depression, anxiety, loss of future-orientation Strongly disturbed autoregulation 
lems, loss of future orientation, anxiety, depression, loss of recovery, and post-traumatic stress reactions. In phase 4 the autoregulation is vigorously disturbed.

\section{Chronobiological reactions during phases 3 and 4}

According to the chrono-bio-psychological BurdenLoad model of Balzer and Stueck (2021), different physiological reactions of the vegetative-emotional system, i.e. the sympathetic-hypothalamic activationdeactivation axis, occur both in the acute (Figure 2, field 6) and in the chronic negative load consequences phase (Figure 2, field 7). This also applies to pandemics. The activity of this axis can be measured, among other things, in electrical skin phenomena (electric skin resistance related to sympathetic activity, whereas electric skin potential relates to nerval, parasympathetic activity (Balzer, 1980; Balzer \& Hecht, 2000a; Boucsein, 2012; Balzer \& Stueck, 2021) and blood pressure (Stueck et al., 2016). It plays a role in maintaining the health-ensuring auto-regulation mechanisms under pandemic conditions, which ensure the adaptation to the new pandemic situations by stabilizing the 'Basic-Rest-Activity Circle' (BRAC-Circle; Kleitman, 1982; Hecht, 1993; Rossi, 1988). With normal autoregulation, e.g. in orientation phase (Figure 2, field 5), $70 \%$ physiological activation states alternate with $30 \%$ deactivation states in this psycho-physiological restactivity rhythm, in each case in 120-minute periods. It can be assumed that this autoregulative chronobiological rhythm is disrupted in the acute and chronic stress phase in pandemics, with the following physiological accompanying reactions or physiological protective functions:

- First, physiological overload inhibitions occur, which can be measured as deactivation states in the skin resistance (Balzer \& Hecht, 2000b; Stueck et al., 2005). The physiological overload inhibitions indicate the overload of the emotional-vegetative system due to the pandemic situation, thereby serving as the first-level protective mechanism against overloading of the vegetative-emotional system in phase 2 .

- Second, failure to cope with the negative effects of negative load consequences leads to unspecific neural activation, measurable in terms of the skin potential, and an associated hypersensitivity (increase in the neural activity of the skin potential) as the second level of protection. These hypersensitive states occur with chronic stress states (Balzer \& Stueck, 2021).

- Third, failure to cope then leads to states of fatigue or exhaustion which can be measured as a decrease in the activity of the skin potential and an associated hyposensitivity (Balzer \& Stueck, 2021; Stueck et al., 2005).

In the study on the pandemic management theory, the hyper- and hyposensitivity could only be queried. An increase in hypersensitivity was noted as the pandemic progressed. Hyper- and hyposensitivity or overload inhibitions are biocentric limits (see chapter Biocentric limits in pandemic situations) that prevent adaptations to living conditions during the pandemic and an inner psychological and physical stability of the biocentric core (for a description of the biocentric core see chapter The biocentric core of the Pandemic Management Theory), e.g. the immune system as the biological basis of healthy identity. A connection to the inner circle of action of the Pandemic Management Theory is visible here (for a description of the inner circle see chapter Theoretical components of the inner circle of the Pandemic Management Theory).

\section{Phase 5 - Phase of onset of illness (Figure 2, field 15)}

In phase 5 , if the pandemic experiences are not coped with for a longer period, psycho-vegetative reactions with disease value with manifested vegetative disorders, solidified protection and defence strategies can develop. This stage includes, among other things, psychopathological reactions (depression, phobias, psychosomatic diseases). The symptoms come about as compensation phenomena for the disease-causing living conditions.

\section{Phase 6-Phase of the positive effects of pandemic situations (Figure 4, field 8)}

As shown in Figure 4, positive coping experiences and load interpretations during a pandemic can also lead to positive effects. If situations are interpreted as challenges or assessed by means of the curiosity reaction, this can lead to positive load reactions with positive consequences (see Table 2).

This phase is characterized by an optimistic attitude towards life and paves the way to a healthy disposition (Figure 4, field 13,14), whereby health is viewed from the perspective of salutogenesis (Figure 5). As Figure 5 shows, the self-regulatory reduction of internal tension counts as the pre-determined breaking point between illness (discomfort, pathogenesis) and health (well-being, salutogenesis), as a turning point for the body to shift towards healthy autoregulation and adaptative learning. According to this concept, illness and health represent a process rather than a state (Figure 5).

The process character of health $(\mathrm{H}-, \mathrm{H}+)$ is supported by internal and external resources (including self-efficacy, psychosocial support, Figure 4, field 12) and protectives factors, such as sense of coherence (Sense of Coherence, see Figure 4, field 12), which is made up of the components of comprehensibility (ability to analyse the situation for its causes) and manageability (knowledge of one's own resources) and meaningfulness (meaningfulness of coping at-
Biocentric health management and COVID-19 
Marcus Stueck

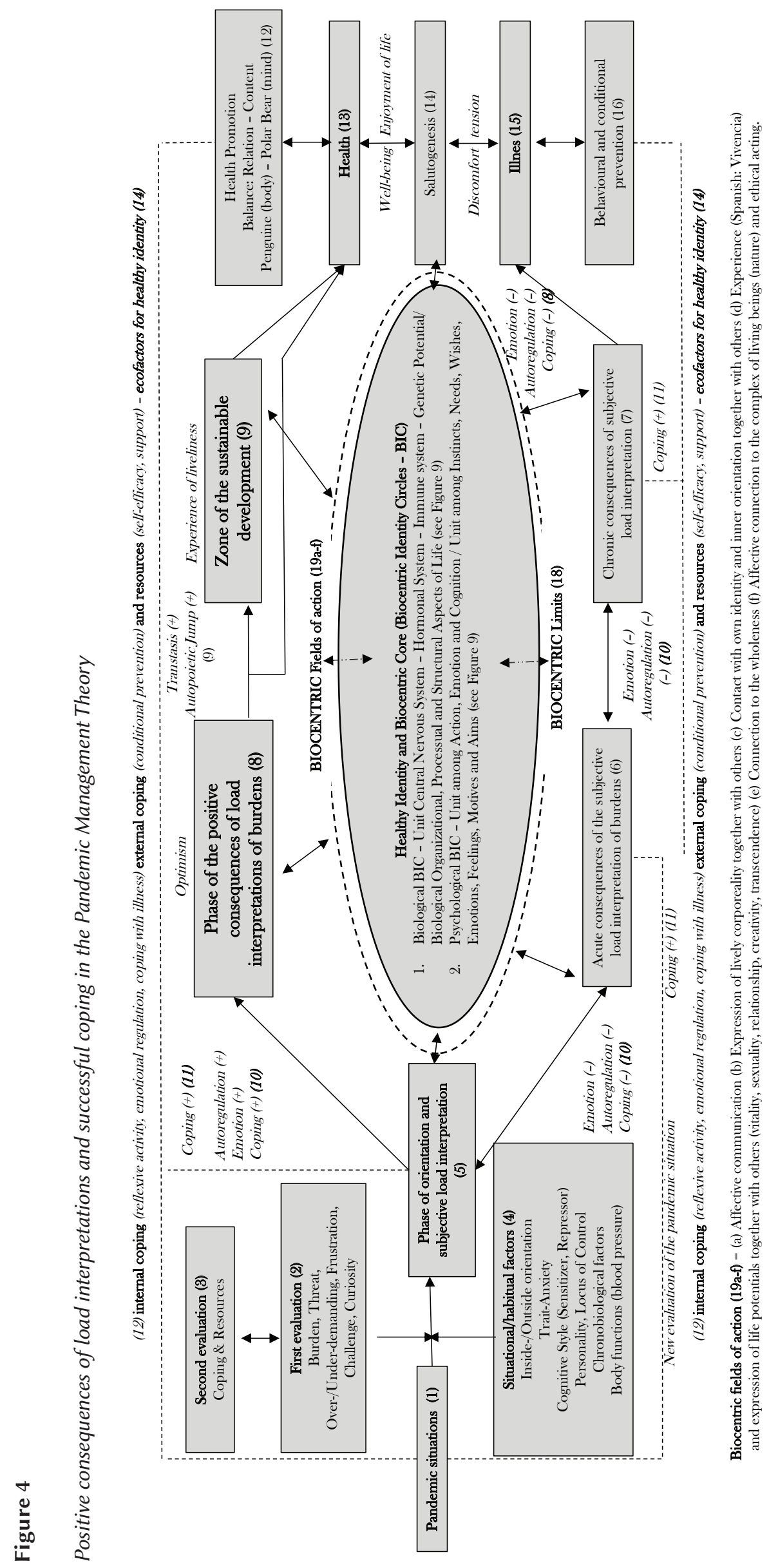


tempts). As described in chapter The biocentric core of the Pandemic Management Theory, next to the psychological coping strategies, also the activity of the biocentric core and the activities in the biocentric fields of action play an important role to maintain health and wellbeing in times of pandemics (see Figure 2, field 17).

Phase 7 - Zone of the next sustainable biocentric development (Figure 1, field 9)

In Phase 6 successful autoregulative and adaptive biological mechanisms of homeostasis (balance) take place (see Figure 4, field 8). In Phase 7 (see Figure 4, field 9) 'developmental autopoietic leaps (= jumps)' can be observed first in biological functions (e.g. central nervous system, hormonal and immunological system), which refers to the eternal movement towards evolution (according to the main law of life). This biological evolution then transfers to psychological dimensions in a self-organizing manner, e.g. associated with an increase in well-being and mood changes or ethical attitudes towards life values (biocentric values, e.g. affective connection and sensibility towards nature as a complex of living beings and protection of it), for instance as a result of Biodanza (Toro, 2010; Stueck \& Villegas, 2009, 2021). This sustainable biocentric evolution can be measured by parameters of psychological development, e.g. in questions about sustainably determined changes in behaviour within the pandemic period of the lockdown, with regard to sustainable nutrition (e.g. question: 'an ecologically conscious food has become my most important in life'...), ecological awareness (e.g. 'protecting the environment...), empathic behaviour (e.g. a loving affective relationship has become the most important life...'). The psychosocial connections to the 'autopoietic leaps' can only be established from this biological perspective (Maturana, 2011; Stueck, 2020a). The term 'autopoiesis' was coined by Maturana and Varela (1991) as a biological concept and means 'self-creation' (ancient Greek: autos - self and poiein - create, build). It describes the process of creating and maintaining a system itself. The term 'autopoietic developmental leap' was defined by Stueck (2021) in the context of the Pandemic Management Theory on the base of the Biocentric Health Management model. It is a processes of "transtasis" as an inner transformation to another evolutive step of integration (Toro, 2010) on the basis of the theory of human evolution by Toro (2010), the autopoiesis model (Maturana \& Varela, 1991) and the model approach to synchronisation and desynchronisation (Balzer, 2009; Balzer \& Stueck, 2021). Autopoietic leaps are caused by 'leaps' in biological systems, when they enter crisis-like states, which creates a jump (developmental leap) to a different level ("transtasis"), e.g. clearly reflected in chronobiologically analysed heart
Figure 5

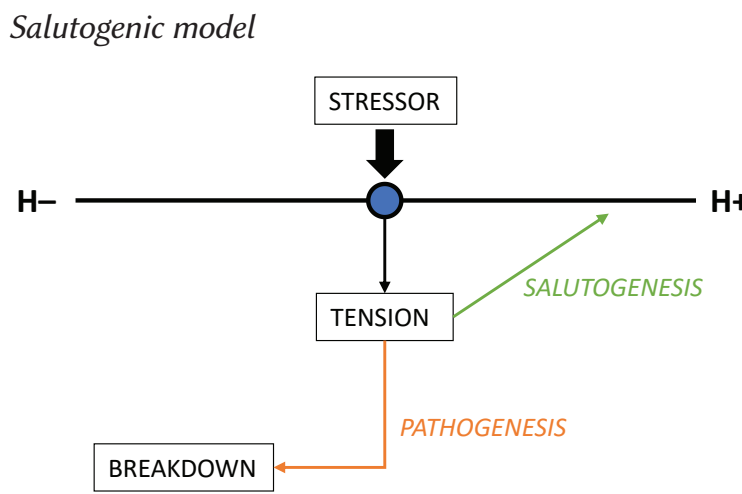

Biocentric health management and COVID-19 rate (Balzer \& Stueck, 2021) and skin response (Balzer \& Hecht, 2000a). Also, it has been demonstrated that, if synchronization and de-synchronization processes for several parameters occur in an alternate fashion, the alternations were correlated with the muscle tension, skin resistance and skin potential (Balzer, 2009; Stück et al., 2005). Stueck et al. (2009) have reported the autopoietic leaps in a time series of immunoglobulin A because of Biodanza in comparison to a Yoga intervention (Stueck et al., 2003, 2009). Important resources for the development of 'autopoietic leaps', which take an individual into the zone of the next development (Vygotskij, 1932/2005; Keiler, 2002) are considered in the Pandemic Management Theory in the following aspects:

- creative, authentic expression of emotions in Biodanza (Toro, 2010; Stueck \& Villegas, 2009; Stueck et al., 2019),

- development of trust, e.g. in the 'Network of Life', as a predetermined direction of movement of systems ("system-teleonomy") (Toro, 2010), reducing control-ambitions (Stueck, 2008),

- development of affectivity (ability to have empathy in action) (Toro, 2010; Stueck et al., 2013), 'group communication in feedback' on a psychological level (Stueck, 2010),

- autonomy of the involved system parameters (Maturana, 2002; Stueck, 2010)

- communication processes between the psychoneuro-immunological parameters in the biocentric core (Schedlowski, 1994; Sack et al., 1998; Koelsch et al., 2016).

The processes of transtasis (autopoietic leaps) and autoregulation run continuously and autonomously in the background in the central nervous system, hormonal and immune systems (see biocentric core, chapter The biocentric core of the Pandemic Management Theory). They are stimulated by the biocentric fields of action (section Biocentric fields of action and biocentric health management in pandemics) and influence the development of a healthy identity (criterias see Table 7) and health-promoting well-being. 
The path includes the orientation towards feelings of happiness (life has meaning, enjoyment, commitment), personal maturation after pandemic stress and post-traumatic growth processes.

\section{CRITERIA FOR THE PHASE TRANSITIONS}

The negative 'predetermined breaking points', i.e. the places in which the individual moves to the next negative stress phases 6 and 7 or positive phases 8 and 9 (Figures 2,4) in pandemic situations are visible and measurable using the criteria selected in Table 3.

\section{DEALING WITH NEGATIVE CONSEQUENCES OF PANDEMIC BURDEN AND LOADS}

In the study on the Pandemic Management Theory 35\% of tested subjects ( $n=403$, German sample) showed fear of becoming sick themselves and $1.7 \%$ developed symptoms characteristic for COVID19. This incidence rate is thus above the average of the overall incidence rate in Germany (1.9\% in May 2020). Nonetheless, $98 \%$ of the healthy community has to cope with the daily pandemic circumstances. The coping efforts trigger an assessment process that can lead to the re-evaluation of the original primary and secondary assessment (Figure 2, fields 1-4). This re-evaluation process enables individual persons to continuously adapt to the constantly changing person-environment transaction. Two coping strategies can be used in the selfmanagement process of pandemics:

Problem-oriented instrumental coping (external coping, Figure 2, field 10): This strategy involves the stress-generating conditions being influenced by the person (Schröder, 1996). This can be achieved for example through problem-solving action or through changes in communication behaviour, the situation, own values and the daily routine (especially time management and communication behaviour during pandemics).
Emotion-centred palliative coping (internal coping, Figure 2, field 10): This involves influencing and regulating the inner milieu (including physical emotional reactions in acute stressful situations, muscle tension, self-reflections) in order to cope with burden or load states and their negative effects. Individuals who can reflect internal processes well and who are not very externally oriented and dependent on the outside world have a good chance of coping well with pandemics. The aim of influencing is to prevent over- or understimulation that would reduce performance (Yerkes Dodson's law). Further health promoting activities during pandemics are shown in Table 4 (Lazarus \& Launier, 1981; Kemper \& Lazarus, 1992; Scheuch \& Schröder, 1990; Schröder, 1996).

The following concrete preventive measures can be proposed by the government to cope with a pandemic (Khankeh et al., 2021):

Entry point control / traffic restrictions.

Risk communication: management of rumours, clear information with scientific evidence, no unrealistic assurances, avoidance of misinterpretation of the low disease risk.

For human resource management in healthcare facilities and hospitals: national guidelines and protocols for staff protection, staff scheduling, volunteer and retiree management, quarantine for staff in health centres, psychological first aid for staff.

The monitoring system, patient flow: free diagnostic and treatment tests for patients, well-trained medical staff and the necessary equipment, establishment of field hospitals.

Resource management and cross-organizational coordination: personal protective equipment (PPE), ventilators, oxygen and diagnostic kits.

Vulnerable groups' management: protecting vulnerable groups, including the elderly, people with underlying diseases, identification and provision of financial support packages for vulnerable and lowincome groups, tax breaks for vulnerable groups, provision of free treatment costs for infected people.

Table 3

Criteria for impaired autoregulatory ability

\begin{tabular}{lll}
\hline Criterion & Negative load phases & Positive load phases \\
\hline $\begin{array}{l}\text { Cognitive } \\
\text { assessments }\end{array}$ & $\begin{array}{l}\text { as stress-threat, frustration-psychological satiety, } \\
\text { overload, underload-monotony, fatigue (Figure 3) }\end{array}$ & as challenge and curiosity \\
Emotional reactions & $\begin{array}{l}\text { e.g. sadness, anger, hope and resignation, fear, } \\
\text { discomfort }\end{array}$ & e.g. optimism, well-being \\
Coping & $\begin{array}{l}\text { lack of coping with stressful situations } \\
\text { (observable in symptoms and duration) }\end{array}$ & successful coping and \\
Autoregulatory ability & limited ability to relax with physiological reactions & successful ability to relax \\
\hline
\end{tabular}


Four activities of health-promoting psychological self-management

Information search and healthy handling of information: Is used to obtain clues to change the way you view the problem. In the study accompanying the PMT, different types of information absorption and processing were found. The displacers need less information, whereas the sensitizers require a lot of information.

Direct action: Serves for the immediate change of burden conditions (instrumental aspect) or for the direct regulation of unpleasant emotions when burden occurs (palliative aspect), e.g.

- By performing relaxation, well-being is achieved.

- Action-related forms of coping as reactions to the topic of illness, e.g. distraction and self-development or active problem-oriented coping.

- Creativity as important resource to regulate emotions to express one's own identity and autonomy.

- The ability to set boundaries (e.g. towards the employer in the home office) and express needs (such as relaxation) is an important psychological ability to ultimately stabilize the immune system.

Inhibition of unhealthy and ineffective actions during pandemics:

- In pandemic situations, there is an imbalance towards too much or too little exercise.

- Eating behaviour is also different, which leads to weight changes.

- Drinking behaviour is restricted under social isolation conditions (Balzer \& Stueck, 2021)

Intrapsychic coping processes:

- Cognitive processes for the regulation of emotions, for the restoration of well-being, for selfrelaxation or positive change in the perception of the situation (distraction, trivialization, denial, intellectualization, self-encouragement).

- Cognitive forms of coping with illness and death (e.g. giving the illness a meaning, searching for religiosity, death meditation).

Maintaining a healthy relationship to physicality: This applies to personal hygiene but also to the daily practice of yoga, tai chi, breath-oriented meditation, dancing.

Emotional forms of coping as preconscious to conscious emotional attitudes towards the illness

(e.g. depressive processing).

Social and psychosocial support: increasing social participation leads to an improvement in social trust and social engagement, participatory approaches such as community participation to support vulnerable groups, creating social distance, pursuing and checking active contacts.

\section{THEORETICAL COMPONENTS OF THE INNER CIRCLE OF THE PANDEMIC MANAGEMENT THEORY}

The model components of the Pandemic Management Theory described in the previous chapters (situation assessment, influencing factors, stress reactions and consequences) are traditional anthropocentric burden-load and stress coping model components within psychology and psychotherapy. They answer the questions in the PMT about the individual burden-load-relationship and how to cope with it during a pandemic period. Because of the fact that the COVID-19 crisis is an existential individual and a collective identity crisis (Stueck, 2021), the inner circle describes the biopsychosocial and biocentric aspects of identity and relationship to others and nature. This anthropocentric and biocentric shift in the theory is explained in the next chapter.

\section{FROM THE ANTHROPOCENTRIC TO THE BIOCENTRIC PARADIGM}

One of the reasons for the emergence of the COVID-19 pandemic crisis, among others, lies in a problematic, ethically questionable attitude and activities of humans towards wild animals in China, where the COVID-19 crisis in Wuhan in December 2019 started (as well as the SARS virus pandemic in 2002 and 2003). The problematic human-animal relationship is worth looking at in order to prevent future pandemics. There can be observed an increased exploitation of animals and nature in general by humans throughout the whole world. The World Wildlife Fund Living Planet Report has noted a dramatic decline in species populations on land $(68 \%)$ and in water (84\%) since 1970 (Almond et al., 2020). The reason for the decline in the Living Planet Index (LPI) is the affective disconnection of humans from nature,
Biocentric health management and COVID-19 
which leads to habitat loss and degradation, including deforestation, driven by how we as humanity produce food. Furthermore, because of the human life style of exploration rather than sustainability, the human species is experiencing a borderline experience with climate change, natural disasters, increasing stress, depression and exhaustion syndromes that arise from the disorder caused by the modern societies, destroying their health and their ability to relate. Here, a paradigm shift is required from the egocentric worldview of anthropocentric (human centred) to biocentric (life centred) in all areas of science and life. In doing so, a choice of co-existence life forms of people and nature would have to be met (see Figure 6).

As seen in Figure 6, in the anthropocentric (Greek 'human' and Latin centrum 'centre') models humans understand themselves as the centre of the worldly reality and solve their problems from this egocentric perspective. The accompanying investigation of the Pandemic Management Theory shows that the way people live in dealing with their environment and nature has been put to the test since this pandemic crisis. According to the Deep Ecology Theory (Naess, 2007) maybe instead of using the construct Nature or Environment, it should be named as a 'living community' or 'complex of living beings' with animals, plants and all living elements in this universe. Because the interpretation of the word 'nature' contains unconsciously an anthropocentric meaning that nature is perceived as something separated from humans. Until now in the anthropocentric paradigm, life values that rely on separations and hierarchies have been developed. The separation of man from the 'rest' of life is an attitude that began along with the intensifying industrialization at the beginning of the 19th century. It has been progressively shifting mankind to a position of a 'ruler' of the world that controls nature and the processes of life. This common conception resulted in the destruction of much of the planet's life-upholding resources (for instance tropical rain forests of the Amazon), without understanding of, or regard for the 'vitality' of the earth as a meta-state and a pre-requisite for the very existence of the life systems, including the species of man, as attributed by Lovelock ("Gaia hypothesis", Lovelock, 2007). In this respect, the COVID-19 is not just an individual, but also a genre-specific identity crisis that affects the entire affective relationship and the structures and processes of life on this earth. The idea of the biocentric approach is that of a 'relationship human, the ecological human' (Toro, 2004, 2010). In western culture it is indispensable to restore the feeling for the 'sanctity and holiness of life', for the 'enjoyment of life' (Schweizer, 1961; Toro, 2010), because this biocentric attitude is left behind. Developing affectivity, expanded embodied cognition, and the expansion of ethical awareness should become an absolute priority (Toro, 2005). The biocentric approach as represented here in the Pandemic Management Theory is based on the following scientific working definition by Stueck (2021):

"The biocentric approach is based on human understanding and feeling of being a part of the complex of all living beings within this universe, based on affective experiences and encounters in feedback. This affective, loving and empathic connection to oneself, to others and to the living community (nature) has to be done both in a group context together with others and by themselves by using the body-oriented, nonverbal and also verbal-reflecting field interventions

\section{Figure 6}

Pyramid model of anthropocentrism vs. network model of biocentric cooperation (source: Pinterest)
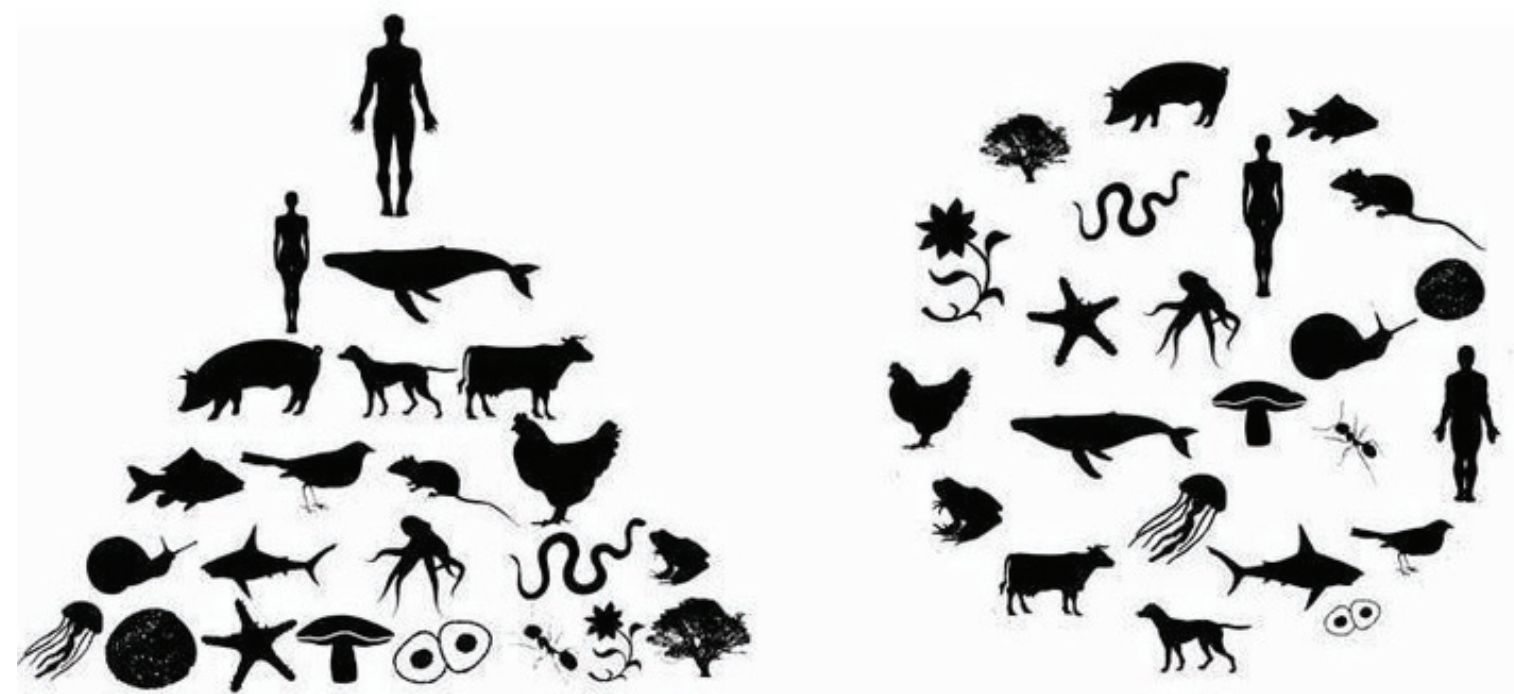
out of the six biocentric fields of action (explanation, see chapter Biocentric fields of action and biocentric health management in pandemics). Through the creation of affective and loving-empathic life protecting thoughts, feelings and behaviours and the integration of instincts, under consideration of existential needs, also through the inside orientation (reflexion) and in connection with the human inner nature and its biological and psychological biocentric coreactivities (explanation, see chapter The biocentric core of the Pandemic Management Theory), all this increases the sensibility towards life. This leads to a dissolution of the biocentric limits (explanation, see chapter Biocentric limits in pandemic situations), e.g. reduction of anxieties, to an affective connection with the complex of living beings and with the sanctity and holiness of Life and to an increase of the ethical consciousness and of the aesthetic recognition of being a part of nature and universe rather than obsessively attempting to dominate them or being disconnected from them. It's a shift from the egocentric, disconnected human to the ecologic, connected human, that produces a leap towards sustainable development in all areas of science, work, education, health and life."

This scientific working definition is based, among others, on the works about:

- the biocentric principle, biocentric education and Biodanza of Toro (2004, 2005, 2010),

- the biocentric principles of Cavalcante and Wagner (2020) and the research on Biodanza (Stueck \& Villegas, 2009, 2020; see www.bionet.name),

- the radical constructivist approach (Maturana, 2002; Maturana \& Varela, 1991), the Biocentric Health Management Theory (Stueck, 2020a, 2021) and the test battery for measuring biocentric acting (Stueck, 2020b; Delshad et al., 2021),

- and psychological risk analysis in institutions ("Health Cube"; Stueck, 2010, 2019),

- and biocentric health management (Stueck, 2021),

- the ethics and reference towards life of Schweitzer (1961, 1999; Barsam, 2008), the ethical behaviour towards animals, animal welfare and justice (Mayr et al., 2010) and plants (Balzer, 2013),

- the complexity of life and nature (Morin, 2001), the fundamentals of knowledge (Morin \& Brümann, 2001),

- respectful communication (Rosenberg, 2009; Müller, 2019), autonomy in education and dialog of cultures (Freire, 2007), school of empathy (Stueck et al., 2013, 2019), deep democracy (Mindell, 1992; Lewis \& Woodhull, 2018),

- environmental biocentric development and understanding (Lovelock, 1991, 2007) and deep ecology (Naess, 1989, 1998, 2013),

- the chronobiopsychological basics of life (Hildebrandt et al., 1998; Stueck et al., 2019; Balzer \& Stueck, 2021).
All these authors, among others, have a common belief that humans must radically change their relationship to nature from the one that values nature solely for its usefulness to human beings to the one that recognizes that nature as a living community has an inherent value which needs to be protected and to cooperate with it. Toro (2010) approaches the importance of the development of affective relationship to oneself and other human beings as a basis for a healthy relationship towards nature: "The genius of our species is not in its intelligence, but in an affectivity which is geared towards tolerance, compassion, friendship and love. Affectivity makes it possible to perceive reality with full meaning, it connects life and gives facts their essential meaning. It permeates the perception of beauty, imagination and understanding" (Toro, 2005, p. 9). In addition to this important biocentric aspect of affectivity, these works link the interdisciplinary network of their approach to connect with life and propose strategies for protecting it in systems of education, medicine, politics, economics, work and psychology. It is an approach that places the laws that govern and protect life as the guide of the pedagogical and methodological model. The biocentric approach orients in various areas of action: personal health but also collective health, social policies and inclusive models of coexistence of the human community (Benatti, 2020).

Figure 7 shows a semantic differential as it was used in the study accompanying the Pandemic Management Theory. It shows the biocentric attitudes (right) as opposed to the anthropocentric ones (left).

\section{THE BIOCENTRIC CORE OF THE PANDEMIC MANAGEMENT THEORY}

The biocentric core was defined within the framework of the biocentric identity model in the centre of the Pandemic Management Theory (see Figure 2, field 17; Figure 9).

The Pandemic Management Theory assumes that the identity, the 'being oneself', has a biological origin, as Toro (2010) stated. The biocentric core consists of biological psycho-neuro-immunological processes, especially in the immune system in connection with the central nervous system (CNS), the hormonal system and gene expression or the epigenetic influence of genes (so called Biological Biocentric Identity Circle 1, BIC; Stueck, 2021) (see Figure 4, field 18). The functioning of these biocentric core components (Biological Biocentric Identity Circle 1, BIC) is threatened by the pandemic. Pandemics have an impact on two processes that are constantly running in the biocentric core (see Figure 9):

a) autoregulation (homeostasis), which ensures adaptation to the environment, and
Biocentric health management and COVID-19 
Figure 7

Anthropocentric versus biocentric attitudes in the world of work (Stueck, 2020a, 2021; modified scheme of Villegas, 2008)

\begin{tabular}{|c|c|c|c|c|c|c|c|c|}
\hline Anthropocentric attitudes & & & & & & & & Biocentric attitudes \\
\hline Myself, I & 1 & 2 & 3 & 4 & 5 & 6 & 7 & We \\
\hline Having & 1 & 2 & 3 & 4 & 5 & 6 & 7 & Being \\
\hline Hierarchy & 1 & 2 & 3 & 4 & 5 & 6 & 7 & Network \\
\hline Short term & 1 & 2 & 3 & 4 & 5 & 6 & 7 & Sustainable \\
\hline Status-oriented & 1 & 2 & 3 & 4 & 5 & 6 & 7 & Process-oriented \\
\hline Routine & 1 & 2 & 3 & 4 & 5 & 6 & 7 & Creative \\
\hline Product-oriented & 1 & 2 & 3 & 4 & 5 & 6 & 7 & Human-oriented \\
\hline Control & 1 & 2 & 3 & 4 & 5 & 6 & 7 & Trust, Loving \\
\hline Passive, reacting & 1 & 2 & 3 & 4 & 5 & 6 & 7 & Proactive acting \\
\hline Problem-oriented & 1 & 2 & 3 & 4 & 5 & 6 & 7 & Solution-oriented \\
\hline Unconsciously & 1 & 2 & 3 & 4 & 5 & 6 & 7 & Deliberately, Awareness \\
\hline Lack & 1 & 2 & 3 & 4 & 5 & 6 & 7 & Abundance \\
\hline Verbal and thinking focussed & 1 & 2 & 3 & 4 & 5 & 6 & 7 & Experience and action focussed \\
\hline Fast, stress & 1 & 2 & 3 & 4 & 5 & 6 & 7 & Slow, relaxation \\
\hline Externally oriented & 1 & 2 & 3 & 4 & 5 & 6 & 7 & Internally observing \\
\hline Imitative & 1 & 2 & 3 & 4 & 5 & 6 & 7 & Authentic, honest \\
\hline Rational & 1 & 2 & 3 & 4 & 5 & 6 & 7 & Instinctive \\
\hline Dependent & 1 & 2 & 3 & 4 & 5 & 6 & 7 & Autonomous \\
\hline Disconnected & 1 & 2 & 3 & 4 & 5 & 6 & 7 & Connected \\
\hline
\end{tabular}

b) autopoiesis, which enables 'developmental leaps' (transtase) in systems through states of stability and instability (process characteristics of life) and structural characteristics of life (communication in feedback, establishing connections and autonomous reactions). The definition of autopoiesis is based on Maturana and Varela (1991).

These two mechanisms of biological systems were described in the biocentric structure and process model (Stueck, 2020a, 2021); see also phase 7, chapter The seven phases of the external circle of the Pandemic Management Theory). The definition of autopoiesis is based on Maturana and Varela (1991). They run continuously in the background of the central nervous system (CNS), hormonal and immune systems to maintain their functioning and development.

It can be assumed that the function of the life- and health-preserving autoregulative and autopoietic mechanisms of the endocrine system are threatened by needs during pandemics. Needs such as the need for environmental control and self-control, the needs for autonomy, self-evolution and social integration. These are states of tension that can be observed in the framework of emotions, which in turn exert an impact on the hormonal system (Figure 8).

The biopsychosocial stress model (see Figure 8; Henry, 1983; Schröder, 1992) shows that stress triggers increased secretion of adrenocorticotropic hormone (ACTH), cortisol and catecholamines, thereby triggering depression, helplessness and threat status. This oscillation between threat (catecholamine-triggered) and helplessness (ACTH-triggered), between hope and resignation (Sisyphus syndrome) is typical of pandemic circumstances. The autoregulative effects of pandemics on the hormonal system in connection with psychological defence mechanisms can be shown based on similar stressful situations. In one of the few studies during the terrorist attacks of 2001, Stueck and colleagues (2005) demonstrated that the stress hormones cortisol and adrenaline increased during the immediate confrontation with the terrorist attacks of September 11, 2001, whereby the information was warded off by the conscious mind. Since we are dealing with a social isolation situation in the pandemic situation with problematic emotions, it can be assumed that social isolation in the pandemic 


\section{Figure 8}

Stress model by Henry (1983; modified by Schröder, 1992)

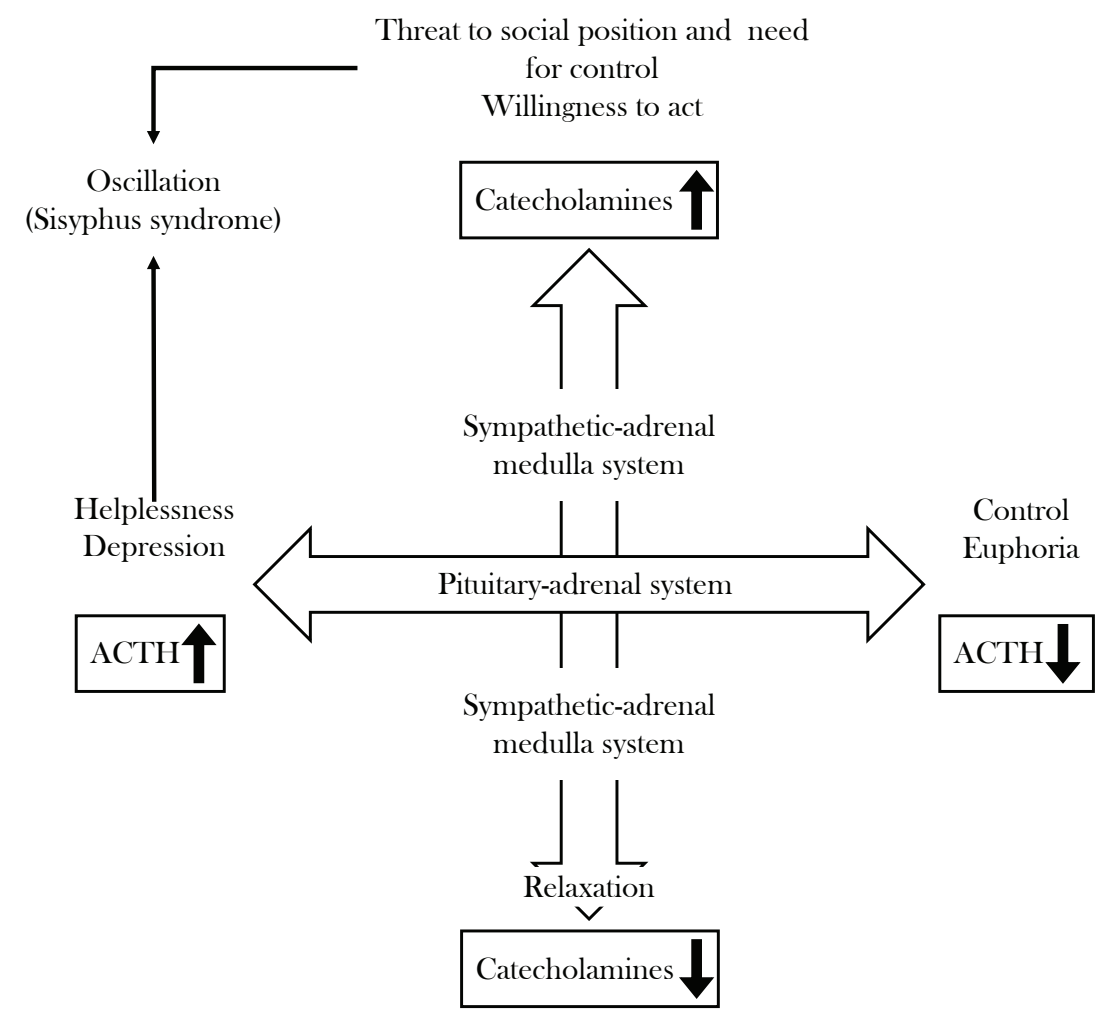

restriction phase can impair the immune system as a biological basis of our identity, as previously shown (Schedlowski, 1994). The biological 'core activities', the so called biological biocentric circle 1, spread into the basic variables of the psyche: behaviour, emotions, cognitions (so called psychological Biocentric Identity Circle 2; Stueck, 2021, see Figure 4, field 18) and influence the process of identity. The optimal functioning of the biological Biocentric Identity Circle 1 (genetic potential, central nervous system, immune and hormonal system) and the psychological Biocentric Identity Circle 2 (instincts, needs, emotions, motives, aims) are internally and externally stimulated by the biocentric fields of actions (see Figure 2, fields $19 \mathrm{a}-\mathrm{f}$ ) and are the basics for health in pandemics.

\section{BIOCENTRIC CORE AND IDENTITY IN PANDEMICS}

The described biological genesis of identity in the biocentric core is accompanied by a psychological identity process which, mediated by emotions, cognitive processes and behaviours, consists of three processes taking place during pandemics in the background:

a) The pulsation between identity (myself) and identification (imitation): Because of this pulsing be- tween identity and identification two processes are constantly running in the background: the internally oriented self-reflection and the self-creation (see Figure 9). In order to shape their own identity, individuals need identification with external models (Petzold, 2012). The external models are largely omitted in pandemics, as public life is very much restricted in the restriction phase and familiar stimuli from the environment are no longer applicable or have changed. In pandemics the person is left to themselves, whereby unpleasant emotions can be intensified. Self-creation leads to a self-organizing development and realization of inherent potential and self-actualization (Rogers, 1959; Braun, 1983; Becker, 1989). For this reason, people who develop internal self-reflection as opposed to external perception and creativity are protected from pandemic stress and its psychological consequences, despite the aroused emotional state (see chapter Biocentric fields of action and biocentric health management in pandemics).

b) The pulsation between individuality (I, ego) and verbal and non-verbal, social cohesion (we, social group) (see Figure 9): These two process levels (a, b), whose 'pulsation' on both levels is limited by pandemics, are embedded in the biocentric core (Figure 9). An identity crisis arises when this pulsation is not possible due to external conditions (e.g. restrictions).
Biocentric health management and COVID-19 
Marcus Stueck

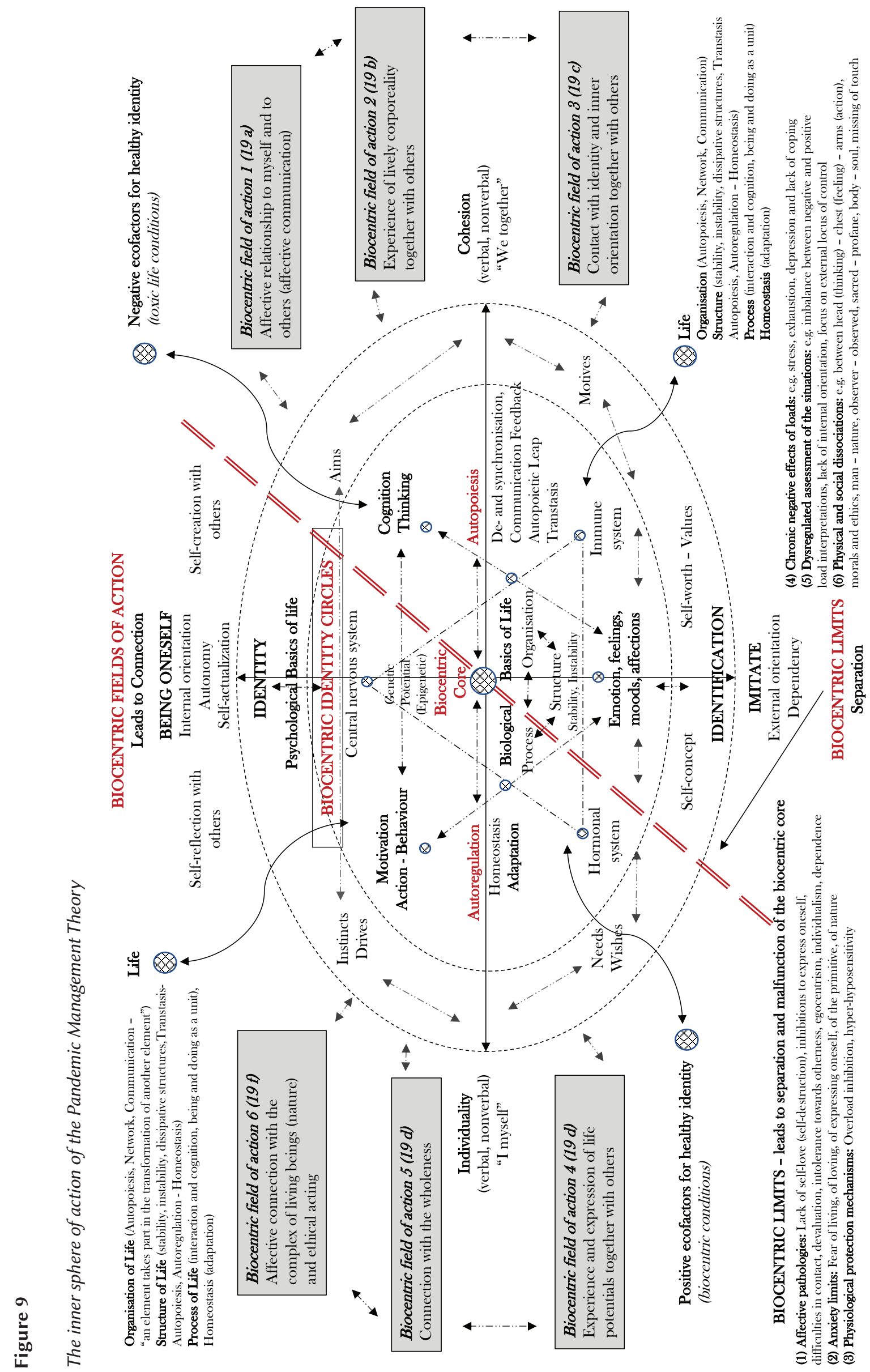


As the study accompanying the Pandemic Management Theory shows, self-reflection and selfcreation (self-actualization, see aspect "a") work for those who can maintain an internally oriented perception. In the accompanying study, an increased internal orientation of perception was visible in $70 \%$ of the test subjects in Germany $(n=403)$. Inner orientation correlates significant with autonomy and the ability to overcome emotional dependency. This is a good coping strategy, since the autonomy is limited by the restrictions in the pandemic situation, but can be maintained or compensated for by internally oriented self-reflection (feeling perception, acceptance of what is observed).

c) Instincts and identity: As shown in Figure 9, the main psychic components (motivation, emotion, cognition, BIC 1) are surrounding the biological biocentric core activities (BIC 2) with their consciously and unconsciously occurring activities that mutually influence each other at the biopsychological level. The motivational factors of behaviour that are positioned around the core include drives, instincts, needs, emotions, motives and aims (BIC 2). Instincts are behavioural dispositions that connect people with life, e.g. the fight and flight instinct or the survival instinct. The survival instinct is very important for pandemics since one faces a threat to life through the risk of infection or one's own illness. The signals of life, the instincts, are threatened in pandemic periods, but also because of dissociations in the culture we live in with a high importance of rational processes in societies which are based on profit-making, exploitation of resources, suppression of sexuality, and dissociations in many other forms. That is why the relation with death in modern societies is so problematic and presents one of the sources of anxiety and compensating behaviour in pandemic or human-made catastrophic circumstances. Studies on mortality salience (awareness of one's own mortality) in the framework of the Terror Management Theory (Greenberg, 2012; Kemper \& Lazarus, 1992) have shown that fear of death switches off the survival instinct in favour of a mental defence strategy (Becker, 1997). One of the thesis of the Pandemic Management Theory is therefore that the identity of people is threatened by more fears than only a fear of death - fear of getting infected and ill or the fear of losing autonomy, which has an impact on self-esteem and cultural values as well as on physical experience and thus ultimately on hormonal and central nervous processes and the stability of the immune system in the biocentric core (Goldenberg et al., 2000). Goldenberg et al. (2000) demonstrated that mortality rates increase the tendency to distance oneself from one's own physicality (lively corporeality). In addition, after becoming aware of one's own mortality, a view on humans which emphasizes the differences to animals is preferred (Tichy, 2013). Here it becomes clear that the access to instincts and the emotions they indicate are disturbed. Through the biocentric fields of action described in chapter Biocentric fields of action and biocentric health management in pandemics this access can be restored.

\section{BODY CONTACT AND IDENTITY IN PANDEMICS}

The second level of the identity processes (aspect "b") running in the biocentric core is about the pulsation between the individuality (the 'I') and the verbal and non-verbal encounter with the other as well as the physical contact associated with it (social cohesion, the 'we'). Pandemics support separations of connections (dissociations) on all levels (e.g. between immune system, hormonal system and CNS, between instincts and behaviour, motor activity and sympathetic arousal, desire for connection and physical separation). In the study, $66 \%$ said they wanted to be hugged and $29 \%$ missed eye contact. The field of vision, which is restricted by wearing masks, also has an important function for emotion recognition, empathy and emotional regulation (Adolphs et al., 1996; Rymarczyk et al., 2019). Touch can be seen as a basic existential need (Wagener, 2000). Davis (1994) summarizes four main areas of meaning of touch:

- biological aspect (physical stimulation),

- communicative aspect (as a transmitter of messages and feelings),

- psychological aspect (communication of security, safety),

- relationship aspect (ability to trust or to be sensitive to other people).

It becomes clear how important the requirement to maintain contact in the biocentric core is. The effects of physical contact are shown in Table 5.

\section{BIOCENTRIC LIMITS IN PANDEMIC SITUATIONS}

A pandemic is a situation of separation, which is why the stimulation of integration of the elements of the biocentric identity circles by activating the biocentric fields of action (see chapter Biocentric fields of action and biocentric health management in pandemics) is so important. The separation between the elements of the biocentric identity circles (see Figure 9) happens because of anxieties and fears, physiological protection mechanisms, body and social dissociations (biocentric limits). The ten most frequently mentioned fears in the accompanying study on the Pandemic Management Theory in Germany $(n=403)$ were: fear of losing autonomy (70\%), fear of getting sick (70\%), fear of losing energy (66\%), fear of the future (64\%), the fear of entering into a relationship with others (59\%), of setting limits (56\%) and of aggression by others $(56 \%)$. The fear of death was visible in $30 \%$ of the cases. Although touch plays an essential role in
Biocentric health management and COVID-19 
our lives and is significantly involved in mental and physical health, it is also closely related to the triggering of fears (Davis, 1994). In the study of the Pandemic Management Theory 55\% of the 403 subjects stated anxieties of being touched by others (55\%) and touching others $(52 \%)$ or taking part in group activities $(50 \%)$. As a conclusion it can be stated that where the pandemic situations trigger fears, so-called fear boundaries become visible, which prevent a connection between the biocentric core and the external life processes. Toro (2011) defined 90 anxieties in four fear boundaries and formulated the request to face these fears in order to stay in contact with life:

- fear of living, e.g. fear of infection, fear of losing autonomy,

- fear of loving, e.g. fear of relating to others,

- fear of expressing oneself, e.g. fear of expressing anger, setting limits,

- fear of natural phenomena, fear of death. In the Terror Management Theory based on Greenberg (2012) it is assumed that fears influence people's self-worth and value system. For Greenberg it was mainly the fear of death that was active during terrorist attacks. In the Pandemic Management Theory, we assume much more fears (see above) that have an influence on the fact that self-worth, as an evaluative part of the self-concept of identity, is destabilized or reinforced and the value structure shifts. Behind these fears is the trait anxiety, as a personality trait (trait characteristic of situational anxiety). It has an influence on the assessment processes in phase 1 (see chapter The seven phases of the external circle of the Pandemic Management Theory) of the pandemic situations that are responsible for the development of fears. In particular, the fearfulness correlates with the threat assessment of the pandemic situations. Here four types of fear processing could be identified with the corresponding frequency of occurrence during the first restriction phase (see Table 6 MarchApril 2020).

The term 'biocentric limits' was defined in this Pandemic Management Theory in order to clarify blockages that exist in the 'biocentric core' of identity due to limited possibilities for self-creation, autonomy, expansion (self-expression) and social exchange processes. Biocentric limits prevent people from a) adapting homeostatically to life processes in the outside world or b) from venturing into the zone of the next development by means of an 'autopoietic leap' (see Figure 4, field 9). The following biocentric limits can be assumed and can be overcome by the activities in biocentric action-fields (see Figure 10):

- affective pathologies: lack of self-love (self-destruction), inhibitions to express oneself, difficul-

\section{Table 5}

Study results on the effects of physical contact

Strengthens the immune system, reduces stress and can relieve tension and pain (mechanism of action; Wagener, 2001, cit. in Stueck, 2008).

Safety and self-protection are conveyed through touch, which is why the sense of touch and feeling is important for adults into old age (Field, 2003, cit. in Stueck, 2008).

A lack of physical closeness can therefore lead to low self-esteem.

In addition, it is generally assumed that a lack of physical proximity promotes a pathological form of attachment and relationship (Gloger-Tippelt, 2012).

Touch has an influence on the organs, identity, emotionality, self-confidence (Toro, 2010).

\section{Table 6}

Cognitive styles of dealing with threatening situations ( $n=200$, German sample)

\begin{tabular}{|c|c|c|c|}
\hline & & \multicolumn{2}{|c|}{ Avoidance of unpleasant emotions } \\
\hline & & Low & High \\
\hline \multirow[t]{4}{*}{$\begin{array}{l}\text { Anxiety - trait } \\
\text { fear }\end{array}$} & Low & $\begin{array}{l}\text { Non-defensive, flexible, } \\
\text { situation-adaptive mode }\end{array}$ & $\begin{array}{l}\text { Repressor, consistent avoidance } \\
\text { mode }\end{array}$ \\
\hline & & $56 \%$ & $16 \%$ \\
\hline & High & Sensitizer, rigid monitoring mode & Highly anxious, inconsistent mode \\
\hline & & $20 \%$ & $8 \%$ \\
\hline
\end{tabular}


ties in contact, devaluation, intolerance towards otherness, egocentrism, individuality, dependence (Toro, 2010; Stueck et al., 2010),

- physiological protective mechanisms (overload inhibition, hyper/hyposensitivity - see chapter The seven phases of the external circle of the Pandemic Management Theory; Balzer \& Stueck, 2021),

- chronic psychophysical consequences of pandemic loads and burdens (e.g. exhaustion, depression, hyperactivity - see chapter The seven phases of the external circle of the Pandemic Management Theory),

- dysregulated evaluations of the situation and permanent outside orientation (see chapter The seven phases of the external circle of the Pandemic Management Theory),

- physical, corporeal dissociations or separations and blockages, for instance between head (thinking) - chest (feeling) - arms (action) (Toro, 2010); this dissociation is the reason for the 'emptying' (the body) during pandemics, i.e. changes in the body feeling due to fears and the loss of autonomy (Stueck, 2007),

- social dissociations (lack of transparency, manipulation, dissociation between morals and ethics, man-nature, observer-observed, sacred-profane, body-soul (Toro, 2010).

The biocentric limits have an impact on a person's attitude to life (liveliness and vitality), well-being and mental and physical health. Consequences of these abnormal sensations are susceptibility to infections, depression and hyperactivity. The connection with life is lost (depression, exhaustion with hyposensitivity states), limits can not longer be set (e.g. in work behaviour) and this effects the immune systeme as a biological basic of identity. Attempts are made to get in contact with the outside world through hyperactive behaviour, although e.g. physiological passivity (in the sense of an overload inhibition) might already indicate the withdrawal behaviour (Balzer \& Stueck, 2021).

\section{CRITERIA FOR A HEALTHY BIOCENTRIC IDENTITY}

The Biocentric Identity Model describes and names methods on how a healthy identity can be maintained in pandemic situations. Table 7 summarizes criteria for a healthy identity (Toro, 2010).

Table 7

Criteria of a healthy identity and their feasibility under pandemic conditions (Toro, 2010)

\begin{tabular}{|c|c|}
\hline Criteria for healthy identity & Effects (German sample) \\
\hline Absence of voluntary aggression & $\begin{array}{l}\text { We determine the increase in the German sample } \\
\text { by means of progress sheets }\end{array}$ \\
\hline Ability to set limits to external aggression & Does not work as measures are defined \\
\hline $\begin{array}{l}\text { The ability to escape in the face of a superior } \\
\text { force }\end{array}$ & Does not work as measures are defined \\
\hline Survival instinct & Does not work \\
\hline Ability to be intimate & Works partially within family \\
\hline Experience of constancy (strength) & Nothing is firmly predictable in this crisis \\
\hline $\begin{array}{l}\text { Maintaining strength (constancy) in the face of } \\
\text { difficulties }\end{array}$ & Nothing is permanent in this crisis \\
\hline Self-determination of the contact limits & Partly, they are imposed from the outside \\
\hline Lack of authoritarian behaviour / power & Authority determines boundaries \\
\hline High level of vitality & $\begin{array}{l}\text { People are exhausted and tired, hypo- or } \\
\text { hyperactive }\end{array}$ \\
\hline Creative skills & $\begin{array}{l}\text { Autonomy is restricted, self-creative persons are } \\
\text { mentally more healthy }\end{array}$ \\
\hline Experience of internalization & Inner orientation should be strengthened \\
\hline $\begin{array}{l}\text { Perception of the other as unique, with unique } \\
\text { inner values }\end{array}$ & Contact behaviour is slowed down \\
\hline Behaviour that happens in feedback with reality & Relation to reality has changed \\
\hline Movements are in balance of energy and synergy & Movements changes due to stress, fast movements \\
\hline
\end{tabular}


BIOCENTRIC FIELDS OF ACTION

AND BIOCENTRIC HEALTH MANAGEMENT

IN PANDEMICS

As has been shown, the identity crisis triggered by pandemics threatens the biological and psychological functions in the biocentric core (see chapter The biocentric core of the Pandemic Management Theory), especially a) the malfunction of autoregulation and self-organisation (autopoiesis), b) the connections to instincts (e.g. survival instinct) and emotions as the signals of life and c) existential needs as motivators to connect with life (e.g. need for environmental control, self-control, self-development, social integration). Therefore, the establishment of the connection through the activities in the biocentric fields of action is of great importance in pandemics (see Figure 10).

One important aspect of the biocentric activities is that they take place in group activities whenever possible, to strengthen the affective connection to others. This is especially important in pandemics, with the risk of social isolation included.

The substance and the aim of the biocentric interventions in these six fields are the life itself and the connection with the 'holiness' and the 'enjoyment' with life. This sanctity of life has been lost in many cultures and the pandemic crisis as an individual and genre-specific identity crisis shows the necessary of gaining this connection again. The methodology for gaining this connection is in all fields mainly the experiential learning at an affective (emotion-based), so called penguin level (Stueck, 2015), rather than an intellectual level (so called polar bear level; Stueck, 2015). Affectivity means developing a feeling-based empathic and ethical and aesthetic rather than moralistic and rational connection to all living beings and elements around (Toro, 2010, 2002; Stueck et al., 2010). The basics of biocentric interventions and education were described by Toro (2004, 2005), who founded the method of Biodanza. Biocentric education teaches the inner basics of how to live as a relationship-oriented and ecological human within a natural and cosmical network (Toro, 2005).

\section{BIOCENTRIC HEALTH MANAGEMENT IN WORKING, EDUCATION, HEALTH RELATED FIELDS FOR ADULTS AND CHILDREN}

There are many possibilities to work with biocentric interventions. The following criteria describe a biocentric intervention:

When it works with experiential learning in groups by doing and experiencing with all senses and affective contact.

When the feedback after the experience is not asking for an analysis, just for expression of feelings by words, art, poetry, the expression is a "sacred" space. When it asks for feelings (what do you feel about), rather than thinking (what do you think about).

When the method works to secure and develop the aspects of healthy identity (see Table 7).

When I work with materials and sounds from nature (e.g. water, sound of wood, voice, singing) or real sounds from musical instruments.

When the feedback leads to self-reflexion, which doesn't get evaluated.

When I get support in crisis or insecurities, and the time to make experiences.

When the exercises in the method strengthen the empathy in the group and are not focused on a single person (perspective of the other).

When the focus of the intervention is on support, not about "what is wrong with you".

When it includes the body orientation, balance between the body-head-way (polar bear) and the headbody-way (penguin) mind in the intervention (see Figure 10).

When the method integrates all aspects of life in the group (all religions, men and women together, inclusion of disabled persons, all ages, animals, e.g. dogs, plants).

When the method is oriented in the "here and now" and is not focused to fast on solutions.

Table 8 shows the levels of interventions related to the biocentric fields of actions.

\section{EVALUATION OF THE PANDEMIC MANAGEMENT THEORY}

The theory was evaluated as a part of a study initiated by the DPFA Academy for Work \& Health in Leipzig, Germany by inviting nine universities worldwide (see Table 9).

The German test sample includes a total of 400 test persons (150 men and 250 women) who had completed the long form of the questionnaire. In Germany, the study began on March 27, 2020, i.e. seven days after the start of the restrictions (March 21, 2020), and lasted until today with effect and process evaluation. The research instrument used for this, the Health Cube questionnaire (Stueck, 2019) for psychological risk assessment during the COVID-19 crisis, analyses on six levels of analysis the situation (level 1), biopsychological factors (level 2), biocentric and psychological resources (levels 3, 4, 5), as well as behavioural and conditional preventive interventions for coping (level 6). A process questionnaire (Form A, B, C) was then sent out at intervals of seven to ten days. Form D was sent to the subjects 20 days apart further forms were given until today. The results of the studies were published in several publications up to now (Bidzan et al., 2020; Bidzan-Bluma et al., 2020). Since 2020 there is research topic in Frontiers of Psychology (Biocentric sustainable development and COVID-19). 


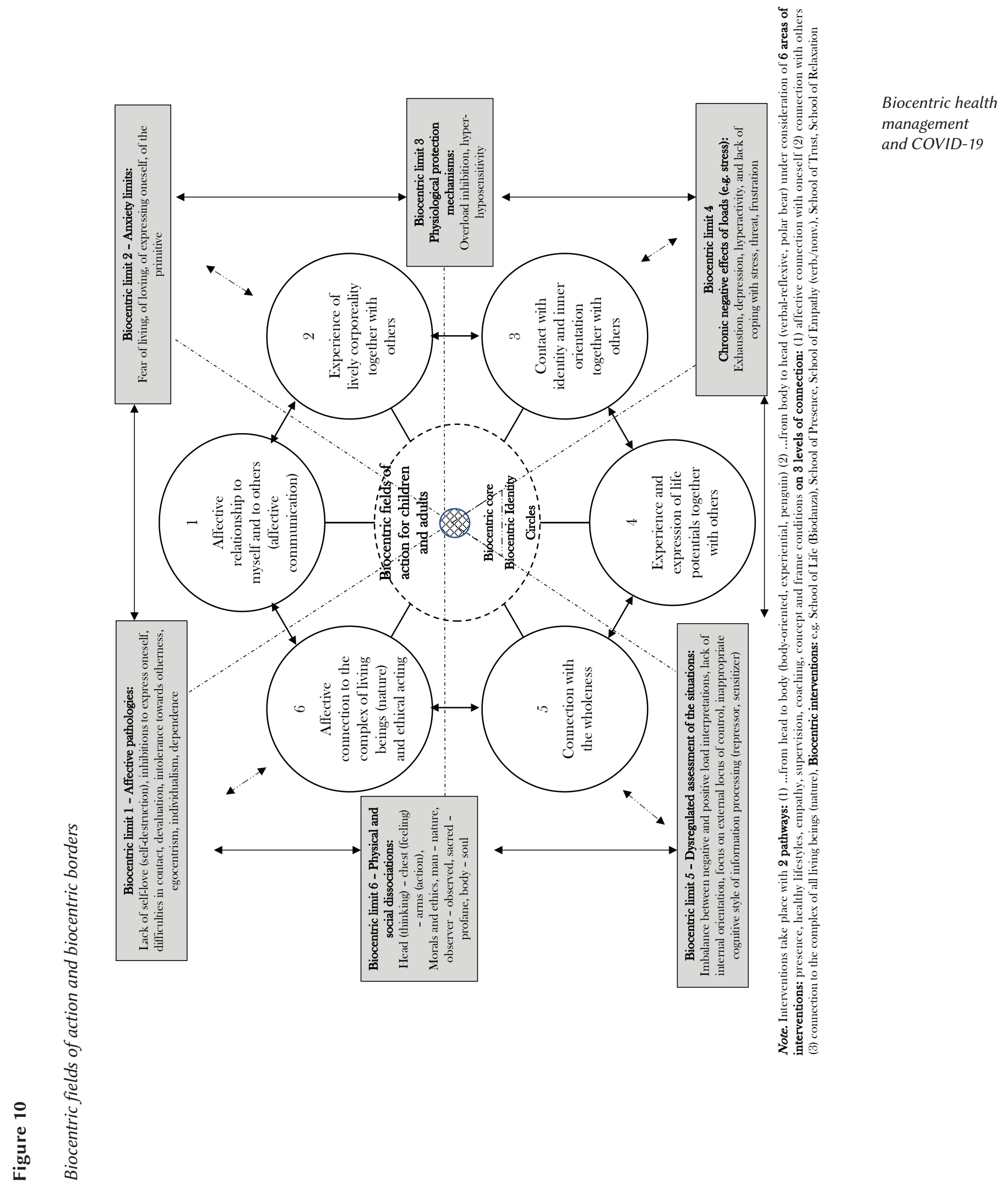


Table 8

Biocentric levels

Biocentric fields Interventions Examples (head to body, experiential, and body to head, verbal-reflexive)

1. Affective Affective, feeling based, Identify with own wishes and realize them, self-love and communication to myself, to connections between self-respect, attitude of self-responsibility and self-creothers humans and themselves

Affective connection to other humans

2. Expression of lively corporeality together with others

3. Contact with healthy identity and inner orientation together with others

4. Experience and expression of life potentials together with others
Connection of wildness and instinctiveness of life

Development of inner orientation

Self-reflection, feedback Internal detachment of dependencies

Identity through affective encounters in feedback

Maintaining autonomy, self-actualization and creative expression

Stimulating the joy of living and the feeling of liveliness

Development of life sense and trust

Experiential integration, subjective construction of knowledge ation, integration of thinking, feeling and acting, taking time and being "lazy", experience of music and movement

Empathy and affectivity to others in thinking, feeling and acting, poetry of encounter (Biodanza), openness to otherness, to form bonds, develop altruistic behaviour, skills of expression of feelings to others, ability to communicate, stop discrimination, self-destruction, recognition of the other, participation and integration of all group members through "deep democracy", "warm shower" of affective words to others, poems

Through music, movement and expression of emotions in the group context (Biodanza), development of kinaesthetic sensitivity and perception (flowing, coordination, eutonia, body enjoyment through gentle massages, caress, organic swimming (warm water)

Breathing, meditation (e.g. Vipassana), praying, tai chi, relaxation, e.g. autogenic training), vivencia-experience of Biodanza

Self-reflection through verbal feedback questions

Internal perception of feelings, authentic expression of needs and wishes, exercises to challenge yourself, defending one's own point of view, to set limits and to connect with one's own strengths

Embraces, holding eye-contact, seeing faces, physical contact, caress, creating situations of verbal and nonverbal encounters with time and in feedback and without interpretations

Aspects of healthy identity, expressing creativity by writing poetry, art, making music, dance, setting limits to influences that restrict autonomy, to reduce stress, to increase relaxation

Biodanza, through common experiences in the social community, through experiences in vitality, affectivity, creativity, sexuality, transcendence, through questioning and critical dialog

Movement, games activities, such as role-play, storytelling and sport in social communities, 're-evaluation of experiences' and the 'analysis of different points of view and alternatives', body-mind interventions

Experience-oriented and enjoyable perception of the living environment with five senses, phantasy work, imagery induced relaxation

Table 8 continues 
Table 8

Table 8 continued

\begin{tabular}{|c|c|c|}
\hline Biocentric fields & Interventions & $\begin{array}{l}\text { Examples (head to body, experiential, and body to head, } \\
\text { verbal-reflexive) }\end{array}$ \\
\hline \multirow[t]{2}{*}{$\begin{array}{l}\text { 5. Connection } \\
\text { to the whole- } \\
\text { ness }\end{array}$} & $\begin{array}{l}\text { Experience of } \\
\text { "implicit orders", } \\
\text { "entanglements", } \\
\text { regression (Toro, 2010) }\end{array}$ & $\begin{array}{l}\text { Organic swimming in warm water, exercises to expand } \\
\text { the consciousness, the integrated trance can be initi- } \\
\text { ated by slow music and movement, relaxation processes, } \\
\text { nature experiences }\end{array}$ \\
\hline & Inclusion & $\begin{array}{l}\text { Inclusive culture (welcoming, teamwork, recognition), } \\
\text { structures (fairness) and practises (social support, activi- } \\
\text { ties outside work) }\end{array}$ \\
\hline \multirow{4}{*}{$\begin{array}{l}\text { 6. Ethical } \\
\text { environmental } \\
\text { action and eco- } \\
\text { logical aware- } \\
\text { ness of nature }\end{array}$} & Ethical behaviour & $\begin{array}{l}\text { Increase of sensibility and aesthetic feelings by percep- } \\
\text { tion with all senses of art, music, human encounter }\end{array}$ \\
\hline & Ecological awareness & $\begin{array}{l}\text { Looking for a place in nature where we feel comfortable } \\
\text { (ecologic nest), nonverbal excursions in nature with } 5 \text { senses }\end{array}$ \\
\hline & $\begin{array}{l}\text { Affective connection to } \\
\text { all living elements }\end{array}$ & $\begin{array}{l}\text { Common experience of the complex of living beings (ele- } \\
\text { ments earth, water, fire, air, trees, animals, plants, natural } \\
\text { sounds, fruits) with all senses }\end{array}$ \\
\hline & $\begin{array}{l}\text { Ecological strategies } \\
\text { with biocentric ap- } \\
\text { proach }\end{array}$ & $\begin{array}{l}\text { Design thinking in balance to design feeling and design act- } \\
\text { ing, sustainability, competitiveness considered from the per- } \\
\text { spective of ecological stability and shared biocentric goals }\end{array}$ \\
\hline
\end{tabular}

Note. The "Penguin-Polar bear concept" was developed in the frame of the biocentric health management by Stueck, 2015. It describes two ways of biocentric interventions: a) the way from body to head symbolized by polar bear, e.g. the language of life, non-violent communication by Rosenberg, b) the way from head to body symbolized by penguin, e.g. the dance of life, Biodanza.

Table 9

Study sample and plan

\begin{tabular}{|c|c|c|c|c|}
\hline \multicolumn{5}{|c|}{ Number of subjects (worldwide, regions) } \\
\hline $\begin{array}{l}\text { Effect evaluation during } \\
\text { coronavirus crisis } \\
\text { Health Cube questionnaire } \\
\text { (effect-pre) }\end{array}$ & $\begin{array}{c}n \\
20.05 .2020\end{array}$ & $\begin{array}{c}\text { Process-evaluation } \\
\text { Health Cube (process) }\end{array}$ & $\begin{array}{c}n \\
10.01 .2021\end{array}$ & $\begin{array}{l}\text { After crisis } \\
\text { Health Cube (post); } \\
\text { planned not in all } \\
\text { countries }\end{array}$ \\
\hline $\begin{array}{l}\text { North Europe (Germany, Poland, } \\
\text { United Kingdom, Latvia, } \\
\text { Norway, Netherlands) }\end{array}$ & 615 & $\begin{array}{l}\text { Germany Form } \\
\text { A, B, C, D, E }\end{array}$ & 900 & All \\
\hline $\begin{array}{l}\text { South Europe (Italy, Portugal, } \\
\text { Spain) }\end{array}$ & 280 & & & All \\
\hline Africa (South Africa, Ethiopia) & 50 & & & \\
\hline $\begin{array}{l}\text { South America (Mexico, } \\
\text { Argentina, Chile) }\end{array}$ & 190 & & & \\
\hline North America (USA, Canada) & 20 & & & \\
\hline South East Asia (Indonesia) & 160 & $A, B$ & & \\
\hline Middle East (Iran, Israel) & 160 & & & \\
\hline Australia & 25 & & & \\
\hline Sum (subjects) & 1500 & & 900 & $N=2400$ \\
\hline
\end{tabular}




\section{CONCLUSIONS}

To be healthy in pandemic periods means to be in a congruent connection between the biological and psychological level and to maintain the basic mechanisms of autoregulation and autopoiesis in the biocentric core, thus the structural character (connection, communication) and the process character (stability, instability). The separations from the inner core of the biocentric identity through the triggering of 'biocentric limits' (e.g. anxiety to lose autonomy, to get infected, hypersensitivity) during pandemics are observable in various aspects:

- Lack of empathy, fearful action, lack of sensitivity and lack of motivation to act in daily life in harmony with nature and co-existent with its living beings, rather than from the perspective of the stronger.

- Lack of contact and physicality, the increasing separation between body and mind, between feeling, thinking and acting, focus on the rational rather than on the instinctive.

- Separation from nature, limited ethical action and ecological awareness.

- Attitude towards the exploitation of nature as a normal process to ensure economic success.

- Unethical treatment of animals and disrespectful treatment of their way of life.

The following core messages can be derived from the pandemic management theory for future development in various areas of life (including work, family, education, pandemic self-management):

- Dealing with incorrect stresses during or after pandemics begins with a well-differentiated observation of the situation and the inner reactions. This requires reflective accompaniment of thoughts and emotions and an internally oriented perception.

- The development of a healthy identity is and will be of crucial importance to cope with pandemics. In this process, the development of leading through interventions in the biocentric fields of action plays an important role in the individual and group context (including the development of a lively corporeality, maintaining physical, loving and empathic contact experiences despite tele-communication and an authentic self-expression in the unity of thinking, feeling and acting, communication skills).

- The development of creative self-expression in particular (expression, experience of autonomy, demarcation) is decisive for the health of the immune system as the biological basis of identity.

- Crises and uncertainties have enormous development potential and lead to lasting changes in attitudes towards life (including trust, process orientation) and in the dissolution of biocentric limits (fears, protective mechanisms, dissolution of blockages, social behaviour).

- Experiences in the COVID-19 pandemic lead to changes in pro-environmental consciousness and to the use of a biocentric worldview in contrast to the anthropocentric and egocentric worldview.

- The development of experience-oriented learning and biocentric education and teaching for our children, especially a healthy relationship with oneself, with others and in dealing with nature, is of decisive importance for the continued existence of humanity and the protection of our planet. Adults can only take children as far as they have already gotten themselves.

\section{ACKNOWLEDGEMENTS}

I wish to thank my colleagues at the DPFA Academy for Work and Health for support and bringing this theory into practise, in particular Franziska Brendel, Jessica Knietzsch, Sebastian Müller-Haugk, Katja Lorenz, Max Reichel, Romy Turuta, Alexander Gellert and the general manager Cathrin Liebold and her father Prof. C. Dietz. Likewise, I want to thank Lena Hamann and Donatella Bazzotti for editing and translating the texts. And I want to thank to the colleagues of the international research network for the study "COVID-19 and psychological processing in the context of biocentric development": Mariola Bidzan, Ilona Bidzan-Bluma, Monika Bidzan (University of Gdansk, Poland), Ulrich Sack (Leipzig University, Germany), Edgar Galindo, Adelinda Candeias (University of Evora, Portugal), Maria Prates Knoke Budde, Tania Aroujo (University Salvador de Bahia, Brasil), Dian Veronika Sakti Kaloeti (Universitas Diponegoro, Semarang, Indonesia), Hamidreza Khankeh, Mariam Ranjbar, Juliet Roudini (University of Social Welfare and Rehabilitation, Teheran), Gunendra Dissanayake, Asanka Bulathawatta, Samudra Senerath (University Colombo, Peradenya, Sri Lanka). I also would like to thank the coordinators in the countries: Donatella Bazzotti (Italy), Michelle Dubrreuil Macek (USA), Pilar de la Cueva (Spain), Kate Clement (Australia), Alejandra Villegas (South America), Manju Pöllmann (Austria), Annette Raykova, Vineta Greaves, Linda Tabore (Latvia). Furthermore, a great thank you goes to Alejandra Villegas (Spain, Argentina) and Giovanna Benatti (Italy) for translating and editing the biocentric part of the theory. I also want to thank my teachers, friends and colleagues: Harry Schröder, Konrad Reschke, Evelyn Witruk, Ulrich Sack, Vuk Savkovic, Hans-Ulrich Balzer, Rolando Toro, Swami Shivananda.

\section{REFERENCES}

Adolphs, R., Damasio, H., Tranel, D., \& Damasio, A. R. (1996). Cortical systems for the recognition of emotion in facial expressions. Journal of Neuroscience, 16, 7678-7687. 
Almond, R. E. A., Grooten, M., \& Petersen, T. (Eds.) (2020). Living Planet Report 2020 - Bending the curve of biodiversity loss. WWF.

Antonovsky, A. (1987). Unraveling the mystery of health. Jossey-Bass.

Balzer, H. U. (1980). Die Entwicklung eines Verfahrens zur Wellenschwingungsmessung [The development of a method for measuring shaft vibrations]. Informationen, 103, 58-66.

Balzer, H. U. (2009). Chronobiology - as a foundation for and an approach to a new understanding of the influence of music. In R. Haas \& V. Brandes (Eds.), Music that works: Contributions of biology, neurophysiology, psychology, sociology, medicine and musicology (pp. 25-81). Springer.

Balzer, H. U. (2013). The fruit orchestra - synchronous regulatory processes in the pulp of fruits: a case study. Biopsychological Basics of Life, 2, 38-45.

Balzer, H. U., \& Hecht, K. (2000a). Chrono-Psychobiologische Regulationsdiagnostik (CRD) - Ein neuer Weg zur objektiven Bestimmung von Gesundheit und Krankheit [Chrono-psychobiological regulation diagnostics (CRD) - a new way to objectively determine health and illness]. In K. Hecht \& H. U. Balzer (Eds.), Stressmanagement, Katastrophenmedizin, Regulationsmedizin, Prävention [Stress management, disaster medicine, regulatory medicine, prevention] (pp. 134-154). Pabst Science Publishers.

Balzer, H. U., \& Hecht, K. (2000b). Tagesverlauf des vegetativ-emotionellen Verhaltens eines Rettungsassistenten und eines Fahrers eines Rettungswagens (Fallbeispiel) [Daily course of the vegetativeemotional behavior of an ambulance assistant and an ambulance driver (case study)]. In K. Hecht \& H. U. Balzer (Eds.), Stressmanagement, Katastrophenmedizin, Regulationsmedizin, Prävention [Stress management, disaster medicine, regulatory medicine, prevention] (pp. 156-162). Pabst Science Publisher.

Balzer, H. U., \& Stueck, M. (2021). Einführung in die Chronopsychobiologie [Introduction to chronopsychobiology]. Manuscript submitted for publication.

Barsam, A. P. (2008). Reverence for life: Albert Schweitzer's great contribution to ethical thought. Oxford University Press.

Becker, E. (1997). The denial of death. Simon \& Schuster.

Becker, P. (1989). Trierer Persönlichkeitsfragebogen [Trier personality questionnaire]. Hogrefe.

Benatti, G. (2020). Deep ecology and Biodanza. Paper presented at International Social and Clinical Biodanza Forum, Vicenza.

Bidzan, M., Bidzan-Bluma, I., Szulman-Wardal, A., Stueck, M., \& Bidzan, M. (2020). Does self-efficacy and emotional control protect hospital staff from COVID-19 anxiety and PTSD symptoms? Psychological functioning of hospital staff after the announcement of COVID-19 coronavirus pandemic.
Frontiers in Psychology, 11, 552583. https://doi. org/10.3389/fpsyg.2020.552583

Bidzan-Bluma, I., Bidzan, M., Jurek, P., Bidzan, L., Knietzsch, J., Stueck, M., \& Bidzan, M. (2020). A Polish and German population study of quality of life, well-being, and life satisfaction in older adults during the COVID-19 pandemic. Frontiers in Psychiatry, 11, 585813. https://doi.org/10.3389/ fpsyt.2020.585813

Boucsein, W. (2012). Electrodermal activity (2nd ed.). Springer.

Braun, U. (1983). Selbstaktualisierung versus Verhaltenskontrolle [Self-actualization versus behavioral control]. Peter Lang.

Cavalcante, R., \& Wagner, C. (2020). Educacion biocentrica [Biocentric education]. Ediciones CDA.

Csikszentmihalyi, M., \& Seligman, M. E. (2000). Positive psychology: an introduction. American Psychologist, 55, 5-14. https://doi.org/10.1037/0003-066X.55.1.5

Davis, P. K. (1994). Die Kraft der Berührung [The power of touch]. Waldthausen.

Delshad, V., Ebadi, A., Gholamreza, H., Khankeh, H., \& Stueck, M. (2021). Validation of a Bio-centric Acting questionnaire based on the Biocentric Health Management Theory (BHMT). Frontiers in Psychology (submitted).

Freire, P. (2007). Bildung und Hoffnung (Vol. 2) [Education and hope]. Waxmann Verlag.

Gloger-Tippelt, G. (2012). Bindungen im Erwachsenenalter. Ein Handbuch für Forschung und Praxis [Bonds in adulthood. A manual for research and practice]. Hans Huber.

Goldenberg, J. L., Pyszczynski, T., Greenberg, J., \& Solomon, S. (2000). Fleeing the body: a terror management perspective on the problem of human corporeality. Personality and Social Psychology Review, 4, 200-218. https://doi.org/10.1207/ S15327957PSPR0403_1

Greenberg, J. (2012). Terror management theory: From genesis to revelations. In P. R. Shaver \& M. Mikulincer (Eds.), Meaning, mortality, and choice: The social psychology of existential concerns (pp. 17-35). American Psychological Association.

Hecht, K. (1993). Besser schlafen - Schöner träumen [Sleep better - dream bette]. ECON-TaschenbuchVerlag.

Henry, J. P. (1983). Coronary heart disease and arousal of the adrenal cortical axis. In T. M. Dembrowski, T. H. Schmidt, \& G. Blümchen (Eds.), Biobehavioral bases of coronary heart disease (pp. 365-381). Karger.

Hildebrandt, G., Moser, M., \& Lehofer, M. (1998). Chronobiologie und Chronomedizin [Chronobiology and chronomedicine]. Hippokrates.

Horowitz, M. J. (2009). Persönlichkeitsstile und Belastungsfolgen [Personality styles and consequences of stress]. In A. Maercker (Ed.), Posttraumatische Belastungsstörungen [Post-traumatic stress disorder] (pp. 237-258). Springer.
Biocentric health management and COVID-19 
Keiler, P. (2002). Lev Vygotskij - ein Leben für die Psychologie [Lev Vygotskij - a life for psychology]. Beltz-Verlag.

Kemper, T. D., \& Lazarus, R. S. (1992). Emotion and adaptation. Contemporary Sociology, 21, 522-523. https://doi.org/10.2307/2075902

Khankeh, H. R., Khorasani-Zavareh, D., Roudini, J., Pourvakhshoori, N., Ahmadi, S., AbbasabadiArab, M., Bajerge, N. M., Delshad, V., Mazhin, S. A., Moghaddam, A. S., Bahrampouri, S., Sack, U., Domres, B., Farrokhi, M., \& Stueck, M (2021). Challenges, strategies, and the lessons learned from COVID-19 to manage second wave: a qualitative multi-method study in the context of Iran. Frontiers in Psychology (submitted).

Kleitman, N. (1982). Basic rest-activity cycle -22 years later. Sleep, 5, 311-317. https://doi.org/10.1093/ sleep/5.4.311

Kobasa, S. C. (1990). Stress resistant personality. In R. E. Ornstein \& C. Swencionis (Eds.), The healing brain: a scientific reader (pp. 112-134). Pergamon Press.

Koelsch, S., Boehlig, A., Hohenadel, M., Nitsche, I., Bauer, K., \& Sack, U. (2016). The impact of acute stress on hormones and cytokines, and how their recovery is affected by music-evoked positive mood. Scientific Reports, 6, 23008. https://doi.org/ 10.1038/srep23008

Lazarus, R. S. (1999). A new synthesis: Stress and emotion. Springer.

Lazarus, R. S., \& Launier, R. (1981). Stressbezogene Transaktionen zwischen Person und Umwelt [Stress-related transactions between the person and the environment]. In J. R. Nitsch (Ed.) Stress: Theorien, Untersuchungen, Massnahmen [Stress: Theories, studies, measures] (pp. 213-259). Huber.

Lewis, M., \& Woodhull, J. (2018). Inside the NO: Five steps to decisions that last. Deep Democracy.

Lovelock, J. (1991). Gaia - Die Erde ist ein Lebewesen [Gaia - The Earth is a living being]. Scherz.

Lovelock, J. E. (2007). Gaias Rache: Warum die Erde sich wehrt [The revenge of Gaia: Why the Earth is fighting back]. List.

Maturana, H. (2002). Vom Sein zum Tun. Die Ursprünge der Biologie des Erkennens [From being to doing. The origins of the biology of cognition]. CarlAuer-Systeme.

Maturana, H. (2011). Die Biologie der Realität [The biology of reality]. Suhrkamp Verlag.

Maturana, H. R. \& Varela, F. J. (1991). Autopoiesis and cognition: The realization of the living. Springer Science \& Business Media.

Mayr, P., Benz-Schwarzburg, J., Binder, R., Birnbacher, D., Bitz, S., Bolliger, G., Brenner, A., Ferrari, A., Günzler, C., Herrmann, K., Lengauer, E., Muratori, C., Schicktanz, S., Schmidt, K., \& Walz, N. (2010). Die Mensch-Tier-Beziehung unter ethischem Aspekt. Literaturbericht 2009/2010 [The human- animal relationship from an ethical point of view. Literature review 2009/2010]. Altex - Alternative to Animal Experimentation.

Mindell, A. (1992). The leader as a martial artist: an introduction to Deep Democracy. Harper Collings Publishers.

Morin, E. (2001). Seven complex lessons in education for the future. UNESCO.

Morin, E., \& Brümann, I. (2001). Die sieben Fundamente des Wissens für eine Erziehung der Zukunft [The seven foundations of knowledge for future education]. Krämer.

Müller, M. (2019). Wertschätzende Kommunikation in der Grundschule. Ein erlebnis- und sprachorientiertes Handbuch in neun Modulen [Appreciative communication in primary school. An experience and language-oriented manual in nine modules]. Books on Demand.

Muthny, F. A. (1990). Zur Spezifität der Krankheitsverarbeitung [The specificity of disease processing]. In F. A. Muthny (Ed.), Krankheitsverarbeitung [Disease processing] (pp. 143-166). Springer.

Naess, A. (1989). Ecology, community and lifestyle. Cambridge University Press.

Naess, A. (1998). Life's philosophy: Reason and feeling in a deeper world. The University of Georgia Press.

Naess, A. (2007). The selected works of Arne Naess (Vol. 1). Springer Science \& Business Media.

Naess, A. (2013). Die Zukunft in unseren Händen: Eine Tiefenökologische Philosophie [The future in our hands: A deep ecological philosophy]. Peter Hammer Verlag.

Petzold, H. G. (2012). Identität: Ein Kernthema moderner Psychotherapie [Identity: a core topic of modern psychotherapy]. Springer.

Reschke, K., \& Schröder, H. (2000). Optimistisch den Stress meistern [Overcoming stress optimistically: a program for health promotion, therapy and rehabilitation]. DGVT-Verlag

Rogers, C. R. (1959). Eine Theorie der Psychotherapie, der Persönlichkeit und der zwischenmenschlichen Beziehungen [A theory of psychotherapy, personality, and interpersonal relationships]. Reinhardt Verlag.

Rohmert, W., \& Rutenfranz, J. (1975). Arbeitswissenschaftliche Beurteilung der Belastung und Beanspruchung an unterschiedlichen industriellen Arbeitsplätzen [Ergonomic assessment of stress and strain at different industrial workplaces]. Bundesminister für Arbeit und Sozialordnung.

Röhr, S., Müller, F., Jung, F., Apfelbacher, C., Seidler, A., \& Riedel-Heller, S. G. (2020). Psychosoziale Folgen von Quarantänemaßnahmen bei schwerwiegenden Coronavirus-Ausbrüchen: ein Rapid Review [Psychosocial impact of quarantine measures during serious coronavirus outbreaks: a rapid review]. Psychiatrische Praxis, 47, 179-189. https://doi. org/10.1055/a-1159-5562 
Rosenberg, M. B. (2007). Gewaltfreie Kommunikation: Eine Sprache des Lebens [Nonviolent communication: a language of life]. Steinbach Sprechende Bücher.

Rossi, E. L. (1988). The psychobiology of mind-body healing: The vision and state of the art. In J. Zeig \& S. Lankton (Eds.), Developing Ericksonian therapy: State of the art (pp. 127-148). Brunner/Mazel.

Rymarczyk, K., Żurawski, L., Jankowiak-Siuda, K., \& Szatkowska, I. (2019). Empathy in facial mimicry of fear and disgust: Simultaneous EMG-fMRI recordings during observation of static and dynamic facial expressions. Frontiers in Psychology, 10, 701. https://doi.org/10.3389/fpsyg.2019.00701

Sack, U., Burkhardt, U., Borte, M., Schädlich, H., Berg, K., \& Emmrich, F. (1998). Age-dependent levels of select immunological mediators in sera of healthy children. Clinical and Diagnostic Laboratory Immunology, 5, 28-32.

Schedlowski, M. (1994). Stress, Hormone und zelluläre Immunfunktionen: ein Beitrag zur Psychoneuroimmunologie [Stress, hormones, and cellular immune functions: a contribution to psychoneuroimmunology]. Spektrum Akademischer Verlag.

Scheuch, K., \& Schröder, H. (1990). Mensch unter Belastung: Stress als ein humanwissenschaftliches Integrationskonzept [People under stress: Stress as a human-scientific integration concept]. Deutscher Verlag Der Wissenschaften.

Schröder, H. (1992). Emotionen - Persönlichkeit - Gesundheitsrisiko [Emotions - personality - health risk]. Psychomed. Zeitschrift Für Psychologie und Medizin, 4, 81-85.

Schröder, H. (1996). Psychologische Interventionsmöglichkeiten bei Stressbelastungen [Psychological intervention options in the event of stress]. In H. Schröder \& K. Reschke (Eds.), Intervention zur Gesundheitsförderung für Klinik und Alltag [Intervention for health promotion for clinics and everyday life] (pp. 7-26). Roderer.

Schröder, H., Brückner, G., Schlüssel, K., Breitkreutz, J., Schlotmann, A., \& Günster, C. (2020). Monitor: Vorerkrankungen mit erhöhtem Risiko für schwere COVID-19-Verläufe [Monitor: Previous illnesses with an increased risk of severe COVID-19 courses]. Wissenschaftliches Institut der AOK (WIdO).

Schweitzer, A. (1999). Die Weltanschauung der Ehrfurcht vor dem Leben [The worldview of reverence for life. C. H. Beck.

Schweitzer, A. (1961). The decay and the restoration of civilization. Unwin Books.

Stueck, M. (2007). Ten steps of stress reduction: The intercultural adapted version of training of stress reduction with elements of relaxation (STRAIMY®International). Peter Lang.

Stueck, M. (2008). Neue Wege: Yoga und Biodanza in der Stressreduktion mit Lehrern [New ways: Yoga and Biodanza in the stress reduction for teachers]. Schibri-Verlag.
Stueck, M. (2009). Das Stressreduktionstraining mit Yogaelementen (STRAIMY) für Sozialpädagogen, Lehrer und Erzieher und andere Belastete Berufsfelder (Kompaktversion für Fortgeschrittene) [The stress reduction training with yoga elements (STRAIMY) for social workers, teachers and educators and other stressful occupational fields (compact version for advanced learners)]. Schibri-Verlag.

Stueck, M. (2010). Kinder, Forscher, Pädagogen - Frühe Bildung auf dem Prüfstand [Children, researchers, educators - early education put to the test]. Schibri-Verlag.

Stueck, M. (2019). The Health Cube. In E. Witruk \& D. S. Utami (Eds.), Studies in Educational and Rehabilitation Psychology (Vol. 8): Traumatic experiences and dyslexia (pp. 112-122). Peter Lang.

Stueck, M. (2020a). The Biocentric Health Management Theory. Peter Lang (in press).

Stueck, M. (2020b). Conception of a test battery for psychometric measurement of biocentric acting. Peter Lang (in press).

Stueck, M. (2021). Die Pandemie Management Theorie im Kontext des Biozentrischen Gesundheitsmanagements (BGM) [The Pandemic Management Theory in the context of biocentric health management]. In M. Stueck (Ed.), Biocentric health management and sustainability (in press). Peter Lang.

Stueck, M., Balzer, H. U., Hecht, K., \& Schröder, H. (2005). Psychological and psychophysiological effects of a high-mountains expedition to Tibet. Journal of Human Performance in Extreme Environments, 8, 11-20. https://doi.org/10.7771/2327-2937.1042

Stueck, M., Balzer, H. U., Mueller S., Utami, D., \& Sack, U. (2019). Das Mobile Gesundheitslabor - Ein Bestandteil des Gesundheitswürfels zur Psychischen Gefährdungs- und Ressourcenbeurteilung im Rahmen des Biozentrischen und Betrieblichen Gesundheitsmanagements (BGM) in Unternehmen und Institutionen [The Mobile Health Laboratory - part of the Mental Health Cube. Risk and resource assessment as part of the biocentric and occupational health management in companies and institutions]. In E. Witruk \& D. S. Utami (Eds.), Educational and Rehabilitation Psychology (Vol. 8): Traumatic experiences and dyslexia. Manuscript submitted for publication.

Stueck, M., Meyer, K., Rigotti, T., Bauer, K., \& Sack, U. (2003). Evaluation of a yoga-based stress management training for teachers: Effects on immunoglobulin A secretion and subjective relaxation. Journal for Meditation and Meditation Research, 3, 59-68.

Stueck, M., Rigotti, T., \& Balzer, H. U. (2005). Wie reagieren Lehrer bei Belastungen? Berufliche Bewältigungsmuster und psychophysiologische Korrelate [How do teachers react to stress? Work related coping styles and psychophysiological correlates]. Psychologie in Erziehung und Unterricht, 52, 250-260.
Biocentric health management and COVID-19 
Stueck, M., Rigotti, T., Roudini, J., Galindo, E., \& Utami, D. S. (2016). Relationship between blood pressure and psychological features of experience and behaviour among teachers. Health Psychology Report, 4, 128-136. https://doi.org/10.5114/ hpr.2016.56853

Stueck, M., Sakti Kaloeti, V., Villegas, A., \& Utami, D. (2019). The influence of Biodanza and School of Empathy verbal - respectful communication on the ability to express emotions and needs: a pilot study among adults in Indonesia. Health Psychology Report, 7, 334-340. https://doi.org/10.5114/ hpr.2019.88665

Stueck, M., Schoppe, S., Lahn, F., \& Toro, R. (2013). Was nützt es sich in jemanden hineinzuversetzen, ohne zu handeln? [What use is it to put yourself in someone's shoes without acting?]. ErgoMed Praktische Arbeitsmedizin, 6, 38-46.

Stueck, M., \& Villegas, A. (2009). Dance towards health. Schibri.

Stueck, M., \& Villegas, A. (2021). Science and Biodanza. Unpublished manuscript.

Stueck, M., Villegas, A., Bauer, K., Terren, R., Toro, V., \& Sack, U. (2009). Psycho-immunological process evaluation of Biodanza. Signum Temporis, 2, 99-113.

Stueck, M., Villegas, A., \& Toro, R. (2010). Norden trifft Süden oder wie die Eisbären zu den Pinguinen kamen: Nonverbale Aspekte Wertschätzender Kommunikation in Kindertagesstätten [North meets South or how the polar bears came to the penguins: Nonverbal aspects of appreciative communication in day care centers]. Schibri.

Stueck, M., Witruk, E., Braun, M., \& Sack, U. (2005). What happened at the 11.9. to us? Studies on biochemical reactions. Unpublished manuscript.

Tichy, L. Z. (2013). Die Terror Management Theorie - Ein kritisches Review mit Bezugnahme auf die Meaning Management Theorie [The Terror Management Theory - a critical review with reference to the Meaning Management Theory]. E-Journal Philosophie der Psychologie, 1-30. Retrieved from http://www.jp.philo.at/texte/TichyL1.pdf

Toro, R. (2004). The biocentric principle. International Biocentric Foundation, Biodanzaschule Leipzig. Unpublished manuscript.

Toro, R. (2005). The biocentric education. International Biocentric Foundation, Biodanzaschule Leipzig. Unpublished manuscript.

Toro, R. (2010). Das System Biodanza [The Biodanza system]. Tinto-Verlag.

Toro, R. (2011). Progetto Minotauro [The Minotaur Project]. Pintore.

Villegas, A. (2008). Dance towards health. Schibri.

Vygotskij, L. S. (1932/2005). Das Problem der Altersstufen [The problem of ages]. In J. Lompscher (Ed.), Ausgewählte Schriften [Selected writings] (pp. 53-90). Lehmanns Media.
Wagener, U. (2000). Fühlen - Tasten - Begreifen: Berührung als Wahrnehmung und Kommunikation [Feeling - touching - understanding: Touch as perception and communication]. Bibliotheks- und Informationssystem der Universität Oldenburg.

Witruk, E., Reschke, K., \& Stueck, M. (2009). Psychische Belastungen von Notfallhelfern [Mental stress of emergency helpers]. Trauma \& Gewalt, 3, 196-208. 